\title{
Community and ecosystem consequences of endophyte symbiosis with tall fescue
}

\author{
JENNIFER A. RUDGERS ${ }^{1}$ and KEITH CLAY ${ }^{2}$ \\ ${ }^{1}$ Dept. of Ecology and Evolutionary Biology, Rice University, Houston TX 77005 USA \\ ${ }^{2}$ Dept. of Biology, Indiana University, Bloomington IN 47405 USA
}

jrudgers@rice.edu

\begin{abstract}
We have investigated community and ecosystem consequences of endophyte symbiosis with tall fescue over the past 13 years. Lolium arundinaceum is the most abundant plant in the eastern USA, and most is infected by the wild-type endophyte Neotyphodium coenophialum in Kentucky 31. We established two large experimental grasslands (in 1994 and in 2000) with E+ and E- seed sown in each on recently ploughed herbaceous vegetation. Other plant species established naturally by seed or vegetative fragments. No other treatments were applied and plots were subject to natural biotic and abiotic variation. A third experiment examine ecological influences on endophyte infection dynamics starting from an intermediate infection frequency. We found wide-ranging consequences of the endophyte from significant effects on soil feedback and decomposition rates, to plant-plant competition, diversity, productivity, invasibility and succession, to plant-herbivore interactions and energy flow to higher trophic levels. Further, we found that herbivore pressure caused rapid increases in infection frequency. Our results suggest that endophyte symbiosis in tall fescue can have a transforming effect on ecological systems.
\end{abstract}

Keywords: Lolium arundinaceum, Neotyphodium coenophialum, soil, competition, herbivory, trophc interactions, predators, MaxQ endophyte

\section{Introduction}

Over the past 13 years we have investigated the community and ecosystem consequences of endophyte symbiosis with tall fescue (Lolium arundinaceum) in a series of long-term and large-scale field experiments in the lower Midwest, USA. A great deal of work by many researchers has been conducted to unravel the evolutionary and genetic history of the tall fescue-endophyte association (Tsai et al. 1994; Craven et al. 2001a, b; Clay \& Schardl 2002; Moon et al. 2004), to understand the effect of endophyte infection on the host plant (De Battista et al. 1990; Rice et al. 1990; West 1994; Malinowski \& Belesky 2000; Newman et al. 2003), and to elucidate the underlying alkaloid biochemistry and impacts on animal consumers (Clay \& Cheplick 1989; Hill et al. 1991; Agee \& Hill 1994; Bush et al. 1997; Panaccione et al. 2001; Popay \& Bonos 2005). Recent efforts have used the tools of molecular biology to create engineered endophyte strains with blocked pathways for alkaloid production (Panaccione et al. 2001; Young et al. 2005). In parallel, natural endophyte variants with different alkaloid production profiles have been incorporated into commercial germplasm (Bouton et al. 2002; Timper et al. 2005). Much research effort has also been devoted to similar questions with perennial ryegrass (Lolium perenne), meadow fescue ( $L$. pratense) and annual ryegrass (L. multiflorum), as well as other grasses of economic importance (e.g., Festuca rubra, Agrostis spp., Hordeum spp., Poa spp., Dactylis glomerata.) (Wilson et al. 1991; White et al. 1992; Bazely et al. 1997; Cheplick \& Cho 2003; Cheplick 2004a, b). New information about endophytes continues to accumulate, showing that endophyte alkaloids may enter the environment in unsuspected ways (Franzluebbers \& Hill 2005; Koulman et al. 2007), and revealing that seed-transmitted, alkaloid-producing clavicipitaceous endophytes may also occur outside of monocotyledonous plants (Kucht et al. 2004).

Independent of the dominant grasses of managed forage and turfgrass systems worldwide, there has been much effort to quantify the diversity and frequency of endophyte-infected grasses in natural systems (Clay \& Leuchtmann 1989; Leuchtmann 1992; Miles et al. 1998; Saikkonen et al. 2000; Moon et al. 2002; Zabalgogeazcoa et al. 2003; Faeth et al. 2006; Wei et al. 2006). However, relative to agronomic systems, many fewer studies in natural systems have examined experimentally how endophyte-infection affects plant performance and interspecific interactions (Pan \& Clay 2002, 2003; Faeth \& Sullivan 2003; Faeth et al. 2004: Tintjer \& Rudgers 2006). The eastern United States is very diverse with grasses infected with Neotyphodiumtype endophytes (White \& Cole 1985, 1986; White 1987; Clay \& Leuchtmann 1989; White et al. 1992) as well as grasses (and sedges) infected with symptomatic, sexual species in the genera Atkinsonella, Balansia, Epichloë and Myriogenospora (Bacon et al. 1975; Rykard et al. 1985; Stovall \& Clay 1988; Clay et al. 1989; Leuchtmann \& Clay 1996). While these grasses have been of little applied interest because endophyte-infection is not vertically-transmitted through seeds, they represent a major component of the diversity of endophytes, of grasses, and of grass/endophyte interactions. With the growing interest in perennial grasses for biofuel production (Tilman et al. 2006), the improved biomass production conferred by endophytes in grasses may be of interest across a wider range of host taxa, regardless of the potential for disruption of grass sexual reproduction by stroma production.

Despite the diversity of past research and work in other systems, tall fescue remains the primary focus of research and the model system for grass-endophyte research. Arguably, most grass endophyte interactions worldwide are between tall fescue and Neotyphodium coenophialum. Tall fescue covers a significant area of the eastern USA, and is increasingly prevalent in South America, Australia, New Zealand, China and Africa. In the lower Midwest region of the USA, most tall fescue occurs on poor soils and is either unmanaged or lightly managed by occasional mowing. Much of this tall fescue was originally planted in the $1950 \mathrm{~s}$ and $1960 \mathrm{~s}$, and has persisted in situ or spread locally from original plantings. Most of it is infected by the endophyte found in variety Kentucky 31 (KY-31). Local collections in Indiana revealed no genetic diversity and the ubiquitous distribution of this single endophyte genotype (Leuchtmann \& Clay 1990).

The results of our studies do not bear directly on highly managed agricultural or turf systems, on tall fescue in other regions, or on other endophyte-infected grass species. However, they are relevant to the primary tall fescue zone in the lower Midwest and upper Southeast of the USA (Ball et al. 1993). Our experimental results were highly consistent across plant communities that were geographically proximal but that differed in species composition, land use history, soil type and topography, suggesting that the 
effects of the endophyte symbiosis are robust and predictable. Moreover, they provide a baseline against which other studies and species can be compared. In total, our research indicates that the endophyte of tall fescue is a keystone species with significant direct and indirect effects on community composition, trophic interactions and ecosystem processes. The integrated and cumulative effect of endophyte symbiosis in tall fescue was far greater than individual taxon-focused studies would suggest.

The goal of this contribution is to provide an overview of the major results of our published and unpublished studies investigating the effects of endophyte infection of tall fescue on interspecific interactions, community composition and diversity, and ecosystem processes, such as primary productivity and decomposition. Our null hypothesis is that endophyte infection has no effect on community and ecosystem properties. In addition, we compare our results to those of other relevant studies through a synthesis of recent literature on the consequences of the tall fescue endophyte for arthropod communities. We use this synthesis to highlight new directions for future research.

\section{Methods}

\section{Field experiment: documenting endophyte effects on} the community

We established two large experimental grasslands (one in 1994 and one in 2000) where E+ or E- seed (KY-31) was sown on recently ploughed herbaceous vegetation. Plot sizes were either $20 \mathrm{~m}$ x 20 $\mathrm{m}(\mathrm{N}=8$, upland site, 1994) or $30 \mathrm{~m} \times 30 \mathrm{~m}(\mathrm{~N}=16$, lowland site, 2000). Details of these sites and local conditions are described in Clay \& Holah (1999) and in Rudgers et al. (2007). Many other plant species established from the seed bank, dispersal or vegetative fragments. Both sites were also colonised by a diverse assemblage of invertebrate and vertebrate animals. Voles (Microtus spp.) were the dominant vertebrate grazer at both sites.

A series of measurements were typically taken twice per year, early in the growing season and then again late in the growing season. Vegetation was sampled by harvesting replicated quadrats $(0.5 \mathrm{~m} \times 0.5 \mathrm{~m})$ randomly distributed across the plots. All above-ground vegetation was collected, sorted by species or into functional groups (tall fescue, other grasses, forbs and litter), and then dried and weighed. These data provided information on plant diversity, dominance, productivity and successional patterns (Clay \& Holah 1999; Matthews \& Clay 2001; Rudgers et al. 2004). In addition, all woody plants were comprehensively censused on an approximately annual basis, identified to species and measured for size (height or dbh) (Rudgers et al. 2007). Voles were sampled by live-trapping and by radio collars (Fortier et al. 2000, 2001; Rudgers et al. 2007). Herbivorous arthropods were sampled by repeated sweep netting and pitfall trapping (Rudgers, unpublished). Spiders were sampled by exhaustive searching though litter in confined subplots, and by quantifying individual webs (Finkes et al. 2006). Alteration of soil properties following growth of E+ vs. E- tall fescue was quantified by taking soil cores from quadrats immediately following vegetation harvests, and then growing three test species in individual soil cores from defined locations (Matthews \& Clay 2001).

\section{Field experiment: understanding ecological factors affecting endophyte frequency}

Separate from these experiments where plots were either sown with $100 \%$ endophyte-infected or uninfected seed, an independent experiment was designed to examine the factors that might cause infection frequency to increase or decrease in mixed populations of tall fescue. A total of sixty $5 \mathrm{~m} \times 5 \mathrm{~m}$ plots were established in the same general area as the 2000 experiment described above (Clay et al. 2005). All plots were sown with a 50:50 mixture of E + and E- seed. Half of the plots were fenced to prevent entry by vertebrate herbivores and half of the plots were sprayed with a general contact insecticide (Malathion) to reduce insect herbivory. The two treatments were alternated with unfenced and unsprayed controls in a $2 \times 2$ design. We occasionally put live traps into fenced plots to remove renegade voles. The frequency of infection in the fescue population was sampled twice per year for 5 years using the tissue-print immunoblot procedure (Gwinn et al. 1991; Hiatt et al. 1999, 2001; Hill et al. 2002). Blots were kindly developed in Chris Schardl's lab at the University of Kentucky. Vegetation was sampled at the end of the study when four $0.5 \mathrm{~m}$ x $0.5 \mathrm{~m}$ quadrats were harvested per plot and separated into four components: tall fescue, other grasses, forbs and litter.

\section{Literature synthesis: how tall fescue-Neotyphodium symbiosis may affect terrestrial food webs}

We also synthesised research conducted during the past 10 years on how the endophyte in tall fescue may affect arthropod food webs. We included only those studies that explicitly manipulated the presence (or type) of endophyte in tall fescue and examined effects on other species. We focused on experimental studies because, while naturally occurring infected and uninfected plants may show differences, effects of the endophyte cannot be separated from characteristics of the plant that may influence the probability or history of endophyte infection. In addition, we concentrated on studies of wild animals (not domesticated species). We also focused on endophyte-mediated influences on fitness related variables and performance of animals rather than on behaviours or preferences because these effects will likely have more direct effects on species distribution and abundance. For each study (Appendix 1), we determined the magnitude of the effect of the endophyte treatment, quantified here as the log response ratio $\mathrm{L}=\ln$ ( mean $_{\text {endophyte-free }} / \mathrm{mean}_{\text {endoph yte }}$ ) (Hedges et al. 1999) to allow for scale-independent comparisons of the strength of the endophyte's influence across studies.

\section{Results and Discussion}

\section{Effect of endophyte infection on plant diversity and productivity}

Twice-yearly sampling of vegetation in the upland plots established in 1994 revealed that endophyte infection of tall fescue led to the competitive dominance of the host and suppression of other plant species (Clay \& Holah 1999). E- plots had less tall fescue, greater biomass of other perennial grasses and more forbs compared to E+ plots (Fig. 1). Of special note was the nearly complete loss of forbs from E+ plots after 4 years (Clay \& Holah 1999). There was no effect of endophyte infection on total productivity, but a strong effect on the proportional contribution of different groups to that productivity. In parallel, species richness in E+ vs. E- plots fluctuated over time with $\mathrm{E}+$ plots having proportionally fewer and fewer species compared with the E- plots. The design of the study allowed us to attribute changes in response variable to either endophyte infection or random environmental variation among plots. For both species richness and composition of biomass, there was no effect of endophyte infection during the first 2 years of the study and all of the variation was between plots. However, after 4 years endophyte infection explained nearly $50 \%$ of the variation in response variables while plot explained very little. These results indicated that endophyte infection was overwhelming environmental variation and causing infected plots to converge among themselves, but diverge from uninfected plots. 
We hypothesise that the primary mechanism driving changes in vegetation between $\mathrm{E}+$ and E- plots is differential herbivory, primarily by voles (see additional evidence below). We suggest that voles are consuming tall fescue in the E- plots, alleviating grazing pressure on other plant species (grasses, forbs, tree seedlings). In contrast, in E+ plots voles avoid $\mathrm{E}+$ fescue and spend more effort finding and consuming other plants species. Thus, E+ tall fescue is the last plant eaten if there is anything else to be found, if it is eaten at all. Like Coleridge's Rime of the Ancient Mariner, "Water, water, every where, nor any drop to drink." These effects are likely to be scale-dependent. At the scale of our experiments and the scale at which tall fescue is normally planted, we expect voles to have little choice about the presence of $\mathrm{E}+$ fescue, because territory sizes are smaller than plot or field sizes (Fortier et al. 2001). If experiments were conducted on a smaller and arguably less realistic scale, voles may be able to concentrate feeding in E- patch types and community-level responses may be less strong. Finally, while voles appear to be a key driver in this system, other mechanisms may also contribute to the altered plant community. Allelopathy (Orr et al. 2005), alteration of decomposition rates and soil communities (Matthews \& Clay 2001; Lemons et al. 2005), direct competition (Clay et al. 1993), and differential insect herbivory (Breen 1994) may play minor roles, and the relative importance of these mechanisms in altering the plant community remains to be determined. A few other studies have compared vegetation in contrasting areas with E+ or E- fescue but they have been uncontrolled, non-experimental or lacking in knowledge about starting conditions. There is a need for more field experiments of the types described here.

\section{Effect of endophyte infection on succession}

In both the upland and lowland experimental tall fescue grasslands, the presence of the endophyte suppressed the natural transition from grassland communities to forests (Rudgers et al. 2007). The endophyte reduced tree abundance by $60-80 \%$ across the two experimental sites. Endophyte symbiosis caused declines in abundance and/or growth of silver maple, red osier dogwood, and white ash, but had no significant influence on the growth or abundance of white mulberry, which was only present at the upland site (1994 planting); thus tree species composition was also affected. Importantly, consumption of tree seedlings by voles (Microtus spp.) was $65 \%$ higher in plots with the endophyte at one (lowland) site where these data were collected (Fig. 2). Vole predation on woody species may be more severe in $\mathrm{E}+$ plots because the dominant plant $(\mathrm{E}+$ tall fescue) was unpalatable to voles and, as a result, voles fed more heavily on other plant species, particularly woody species. Finally, the presence of the endophyte in tall fescue had the overall effect of stabilising the plant community by significantly reducing temporal fluctuations in the presence of both woody and herbaceous plant species. Despite its negligible contribution to community biomass, the endophyte imposes an important constraint on the natural transition from grasslands to forests in the Midwest.

\section{Effects on the relation of diversity, productivity and invasability}

A large number of studies in community ecology during the past decade have investigated the impacts of biodiversity on ecosystem functioning (Hooper \& Vitousek 1997; Tilman 1999). We examined the relationship between diversity and productivity and invasibility in relation to endophyte infection of tall fescue. Using a graphical model, we predicted that endophyte infection would weaken the predicted negative correlation between species diversity and ecosystem properties, such as productivity or the success of an invader. We tested this model using field data from the $100 \% \mathrm{E}+$ and $100 \% \mathrm{E}$ - field plots at the upland site, which supported a diverse array of other plant species (Rudgers et al. 2004). We also constructed a greenhouse experiment that experimentally varied the diversity of native prairie perennials in pots (Rudgers et al. 2005). Once prairie communities established, we added E+ or E- tall fescue as an invader. In both field and greenhouse studies, we found that endophyte infection in the invader weakened the negative relationship between plant species diversity and the establishment of the invader (Fig. 3). These results have important implications for understanding how endophytes can alter the effects of biodiversity on invasion and other key ecosystem processes.

\section{Effects of endophyte infection on soil and subsequent plant growth}

Most prior research has focused on the above-ground environment of tall fescue and how the endophyte affects plant performance and interspecific interactions. Although the endophyte does not occur in roots, there may be indirect effects on below-ground properties and processes (Pedersen et al. 1988; Chu-chou et al. 1992; Grewal et al. 1995; Malinowski et al. 1998; Franzluebbers \& Hill 2005). Here, to determine if the growth of E+vs. E- fescue affects subsequent plant growth in the same soil, soil cores were removed from $\mathrm{E}+$ or $\mathrm{E}$ - experimental plots following vegetation sampling, and then planted with E+ or E- tall fescue, Plantago lanceolata or Trifolium repens. The growth of those species was analysed in relation to the past endophyte status of the plot and the composition of the harvested above-ground vegetation. We found that the endophyte status of the plot from which cores were obtained had no direct effect on plant performance (Matthews \& Clay 2001). However, experimental plant responses suggest that, by inducing changes in plant community composition, $\mathrm{E}+$ fescue may indirectly affect soil properties. In particular, there was a decrease in tall fescue biomass when grown in soil previously dominated by E+ fescue, compared to soil previously dominated by Kentucky bluegrass and quackgrass (Fig. 4). This is indicative of negative feedback (accumulation of detrimental organisms) on the growth of $\mathrm{E}+$ fescue, and represents a potential long-term constraint on its ecological dominance. Interestingly, this feedback was endophyte specific as no effect was seen on E- fescue or in soil previously dominated by E- fescue.

Another important soil process is decomposition of litter and other organic matter. In the lowland field experiment, we used reciprocal transplants of $\mathrm{E}+$ and $\mathrm{E}$ - litter into $\mathrm{E}+$ or $\mathrm{E}$ - plots (Lemons et al. 2005). After 10 months in the field, decomposition of the litter was significantly slower for $\mathrm{E}+$ fescue litter than for E- litter (Fig. 5). Decomposition also depended on a complex interaction between the litter source (collected from E+ or Eplots), the decomposition microenvironment (E+ or E- plots), and the presence of mesoinvertebrates (manipulated by the mesh size of litter bags). When mesoinvertebrates were excluded using fine mesh and litter was placed in a microenvironment with the endophyte, the difference between E+ and E- litter was strongest.

Several prior studies have examined the potential effect of endophyte infection on soil properties and processes. For example, Omacini et al. (2004) found that litter decomposition in microcosms using Lolium multiflorum was affected by endophyte status. Similarly, Franzluebbers and colleagues have demonstrated significant changes in soil carbon and nitrogen pools, and alkaloid levels, in soils beneath E+ vs. E- tall fescue (Franzluebbers et al. 
1999; Franzluebbers \& Hill 2005; Franzluebbers \& Stuedemann 2005; Franzluebbers 2006). Other studies have demonstrated changes in mycorrhizal and nematode communities with endophyte infection (West et al. 1988; Kimmons et al. 1990; Chu-chou et al. 1992; Omacini et al. 2006). All of these alterations could feed back onto plant performance of both tall fescue and neighbouring plant species (Orr et al. 2005). At this stage, it remains unclear to what degree changes in soil properties and communities influence aboveground shifts in community composition. This area is ripe for further investigation.

\section{Factors affecting infection dynamics in mixed populations}

Our prior field experiments were conducted in plots with near $100 \% \mathrm{E}+$ or near $100 \% \mathrm{E}$ - tall fescue. This design makes it easy to detect effects of the endophyte, and reflects the common all or nothing endophyte status of many populations of tall fescue (Clay 1997). However, many if not most populations of grass species have intermediate levels of infection (Latch et al. 1987; Shelby \& Dalrymple 1987; Saikkonen et al. 2000; Spyreas et al. 2001). The question arises whether intermediate infection frequencies are stable or change in a directional way towards complete infection or loss of infection. In the latter case, what ecological factors drive infection frequency changes? We established replicated plots with tall fescue at 50\% infection frequency and manipulated herbivore pressure by a combination of fencing and/or insecticide application with controls. There was a rapid increase in infection frequency from $50 \%$ to $80 \%$ over a 5 -year period in unfenced, unsprayed plots subject to the greatest herbivore pressure (Fig. 6, Clay et al. 2005). In contrast, the smallest increase in infection frequency occurred in plots with the least herbivory. These results clearly show that herbivores select for highly infected tall fescue, at least under our experimental conditions, and strongly support the defensive mutualism hypothesis (Clay 1988). However, endophyte-infection frequency increased under all treatments

Figure 1 Changes in biomass composition. We divided total standing biomass into three proportions: tall fescue, other grasses, and forbs. Both the proportion of tall fescue and proportion of grasses other than fescue changed linearly over time depending on the infection status of the plot $\left(\mathrm{F}_{1,6}\right.$ $=11.51, P=0.015 ; F_{1,6}=13.16, P=0.011$ for fescue and other grasses, respectively). The proportion of forb species did not change linearly through time depending on infection status $\left(F_{1,6}=4.41 ; P=0.081\right)$ but has significantly decreased generally through time $\left(F_{1,6}=48.87 ; P=0.0004\right)$. Statistics are the results of repeated measures ANOVA using plot means and a first-degree polynomial contrast for time. Reprinted with permission from Clay \& Holah (1999).

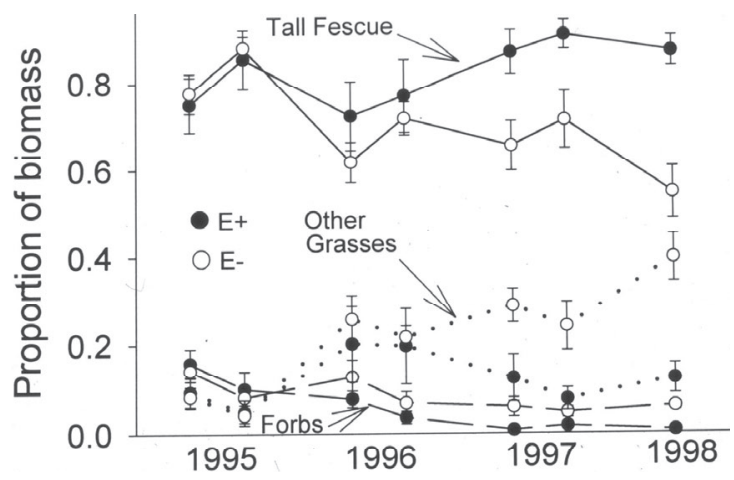

indicating that other factors may also favour infected fescue (Fig. 6). Alternatively, our treatments were not $100 \%$ effective and the uncontrolled herbivory may be responsible for the overall increase in infection frequency. In any case, these results emphasise that the tall fescue/endophyte relationship is highly mutualistic under normal circumstances in its introduced range (but see Cheplick et al. 1989).

Several other studies have followed changes in infection frequency over time, but have generally not applied any experimental treatments (Thompson et al. 1989; Shelby \& Dalrymple 1993). In one notable case with perennial ryegrass, Argentine stem weevil herbivory (Francis \& Baird 1989) led to the rapid loss of uninfected ryegrass seedlings from populations. To our knowledge, in all studies where infection frequency was monitored over time, endophyte infection frequency either increased or remained the same but never decreased in the same population. However, there have been relatively few studies of this type, and more are needed from a variety of species. In particular, could there be frequency dependence such that the relative fitness advantage of $\mathrm{E}+$ fescue depends on the overall infection level in the population? Given that animals may be able to detoxify alkaloids up to a certain point,

Figure 2 Fates of tree seedlings planted into lowland plots enriched with endophyte-infected ( $E+$, filled bars) or endophyte-free (E-, open bars) tall fescue. (A) Mean percentage seedling predation by voles per plot (endophyte $F_{1,56}=12.7, P=0.0008, n=8$ plots), and (B) mean percentage survival per plot after three months (endophyte $F_{1,42}=7.5$, $\mathrm{P}=0.009, \mathrm{n}=8$ plots - black cherry not included in this analysis because no plants survived). With the exception of black cherry survival, the tree species responded similarly to the endophyte (endophyte $\times$ species, predation $F_{3,56}=1.3$, $P=0.3$; survival $F_{2,42}=0.8, P=0.5$ ). Bars show means + s.e.m. Reprinted with permission from Rudgers et al. (2007).
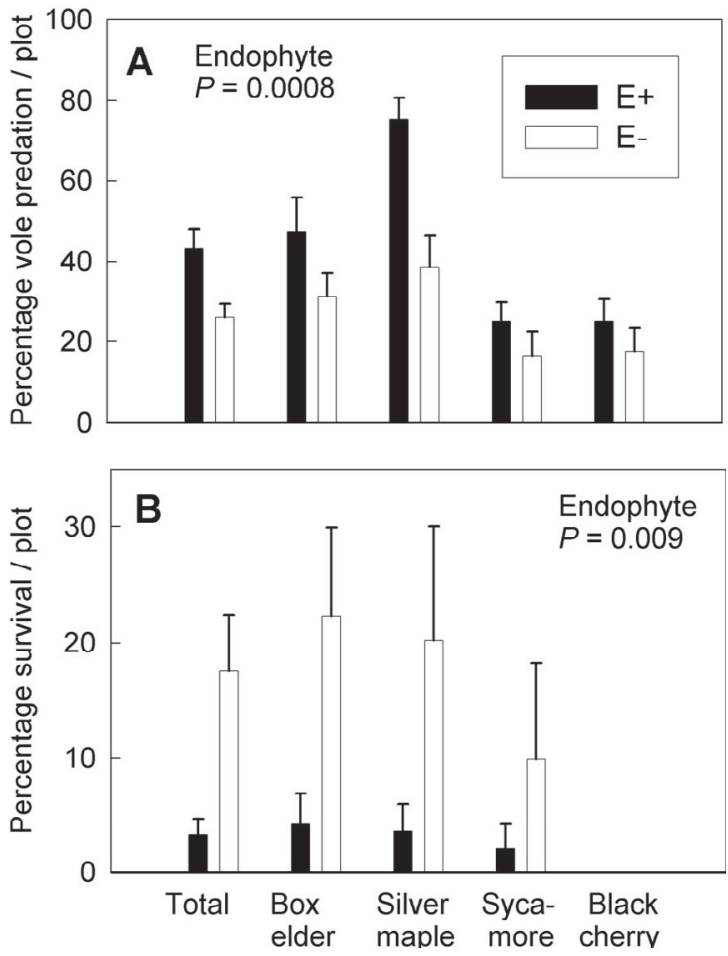
endophyte infection may provide no defense if its frequency is low, or the host is rare. It remains a theoretical dilemma to explain how purely seed-transmitted symbionts can be maintained unless the relationship is mutualistic (Lipsitch et al. 1995; Lipsitch et al. 1996). Near 100\% infection frequencies may provide de facto evidence of mutualism.

\section{Literature synthesis: how endophyte symbiosis may affect terrestrial food webs \\ Aboveground herbivores and seed predators}

The Neotyphodium endophyte in tall fescue can strongly reduce the abundance of individual herbivores. Insects adversely affected by endophytes are taxonomically diverse, including generalist as well as grass specialist species in the Lepidoptera, Orthoptera, Hemiptera, Diptera, and Coleoptera (reviewed by (Latch 1993; Breen 1994; Clay 1996; Rudgers et al. 2005; see also species list, Table 2 in Clement et al. 1994). In our survey of the recent literature, the strength of the endophyte effect differed among types of feeding guilds, with the strongest effects on leaf chewers and more moderate effects on sap (xylem and phloem) feeders. In addition, effect sizes were stronger for species characterised as grass specialists than for species known to consume a broader diet (generalists), perhaps resulting from the ability of generalists to dilute the toxic effects of fungal alkaloids

Figure 3 The number of surviving Lolium arundinaceum individuals by initial plant species diversity (a) without the endophyte, Neotyphodium coenophialum (E-) (regression: Number $=-1.35^{\prime}$ initial diversity $+5.37, r=-0.36, P=0.0018$, $\mathrm{n}=72)$ and $(\mathrm{b})$ with the endophyte $(\mathrm{E}+)$ (regression: Number $=-0.31 \times$ initial diversity $+5.37, r=-0.08, P=0.53, n=72)$. Reprinted with permission from Rudgers et al. (2004).

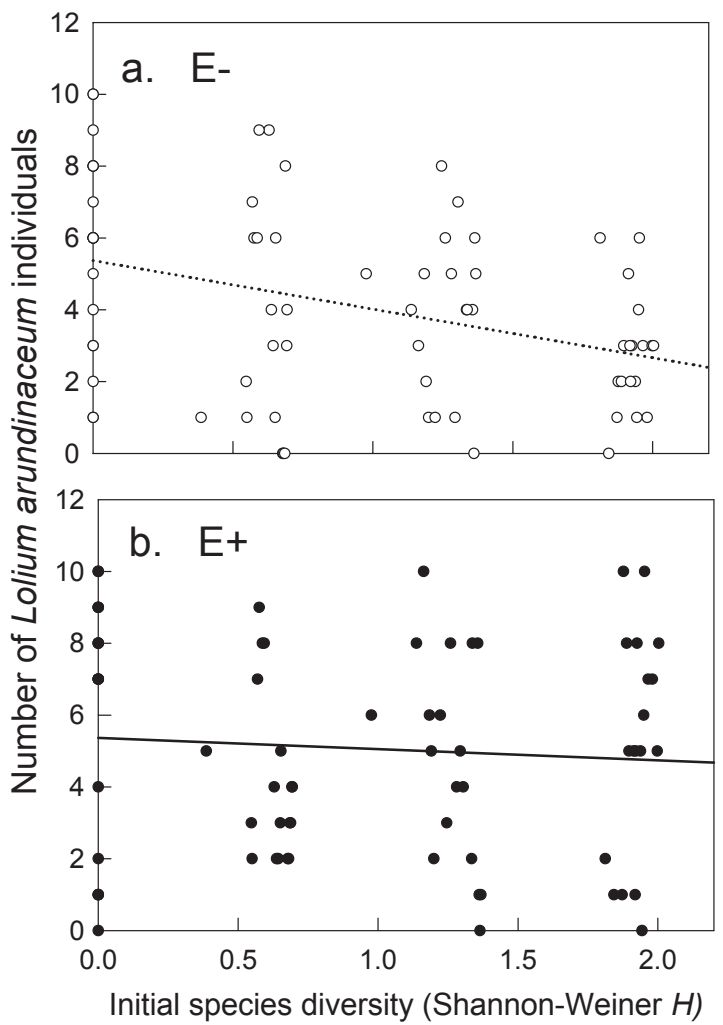

with a more diverse diet. However, surprisingly few total species have been investigated in detail given the wide range of possible organisms that could occur in fields where tall fescue grows, and most studies, not unexpectedly, have focused on important grass pest species.

Because the endophyte is seed-transmitted, there also exists the potential for seed predator deterrence. Although few studies have been conducted, available information suggests endophytemediated deterrence of seed predators can occur. For example, using a novel food source (seeds of tall fescue) presented to seed harvesting ants, (Knoch et al. 1993) showed that the ant Pogonomyrmex rugosus harvested more endophyte-free than endophyte-infected seeds; however, the related species, $P$. occidentalis had no preference. Madej \& Clay (1991) found that a number of passerine birds discriminated against $\mathrm{E}+$ fescue seed. In our review of the recent literature, we found very weak effect sizes for the endophyte's influence on vertebrate seed predators (no recent invertebrate studies have been conducted), especially relative to endophyte effects on vertebrate leaf chewers (rabbits, mice, voles, etc.) (Appendix 1).

\section{Belowground herbivores and detritivores}

Despite the localisation of Neotyphodium coenophialum in aboveground tissues, root-feeding insects and detritivores can be inhibited by endophyte infection. For example, Elmi et al. (2000) found complete mortality of the root knot nematode (Meloidogyne marylandi) in pots of endophyte-infected, but not in uninfected tall fescue. Similarly, survival of Japanese beetle (Popillia japonica) larvae belowground was reduced in pots of highly infected tall fescue compared to pots containing lower infection levels (Oliver et al. 1990), although across field and lab studies, results for endophyte effects on Japanese beetles have been equivocal. Our review of current literature shows much smaller effect sizes for the endophyte on root feeders than any other herbivorous group excepting vertebrate seed predators. Weak effects on root feeders are not unexpected, given that the endophyte is localised in aboveground plant tissues

Figure 4 Regressions of experimental E+ Lolium arundianceum total biomass on previous biomass of Poa pratensis, Dactylis glomerata, Poa compressa, Bromus commutatus, and Agrostis alba, relative to other plants species in soil from $\mathrm{E}+$ plots (filled squares and solid line: $F_{1,78}=21.37, P<0.0001, r^{2}=0.22$ ) and in soil from $E$ plots (open squares and dashed line: $F_{1,78}=0.17, P=0.68$, $\left.r^{2}=0.002\right)$. Relative biomasses were proportions and were arcsine square-root transformed before analyses. Reprinted with permission from Matthews \& Clay (2000).

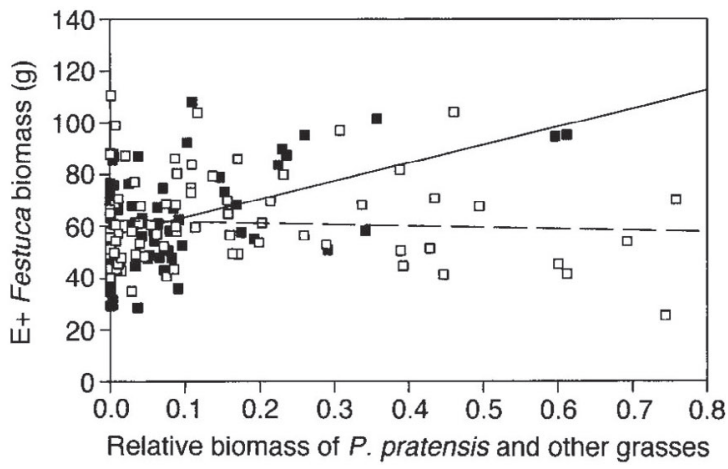


In addition to changes in belowground herbivores, we (and others) have found plot-level changes in the detritivore assemblage. However, overall endophyte-mediated effects on detritivores were small ( $85 \%$ smaller effect sizes) relative to effects on invertebrate herbivores. Previous plot level studies show declines in some detritivores, including chloropid flies, oribatid mites, the collembolan species Lepidocyrtus cinereus, and the reproductive output of earthworms (Bernard et al. 1997; Humphries et al. 2001). However, a few species appear to be unaffected or even enhanced by endophytes (e.g. earthworms, sminthurid collembola (Davidson \& Potter 1995; Bernard et al. 1997), Hypogastruridae (Lemons et al. 2005)). In our work, the total abundance of one keystone detritivore group, the Collembola, did not significantly differ between endophyte treatments (E+ vs. E-), but the composition of collembolan families significantly diverged (Lemons et al. 2005). Specifically, the abundance of Hypogastruridae was greater in E+ plots while Isotomidae abundance was higher in E- plots. These results are consistent with other studies that demonstrate Hypogastruridae tolerate toxic environments (e.g. waste dumps and heavy metal sites) and Isotomidae are especially sensitive to environmental toxins (Fountain \& Hopkin 2005). A broader examination of the decomposer food web is needed. Further, the mechanisms underlying shifts in the detritivore assemblage due to the endophyte remain unresolved.

\section{Predators and parasitoids}

Endophytes, particularly through their effects on insect herbivores, can indirectly modify the abundance or composition of higher trophic levels. Indirect effects may occur through endophyte-mediated reductions in the quality or abundance of prey or through changes in prey behaviour. Moving up through the food web, the effects of endophytes may remain similarly strong, accumulate, or attenuate. Most studies to date support attenuation of endophyte effects on arthropod predators and parasitoids, with an effect size of the endophyte that is $90 \%$

Figure 5 Effect of the endophyte (Neotyphodium coenophialum) treatment on the percentage remaining dry mass of litter from field plots of Lolium arundinaceum over three census dates. $\mathrm{E}_{+}=$litter with the endophyte, $\mathrm{E}-$ = litter lacking the endophyte. Bars represent means with s.e. Sample sizes (number of litter bags) are given on each bar; unequal sample sizes resulted from some bags being lost or damaged in the field. Reprinted with permission from Lemons et al. (2005).

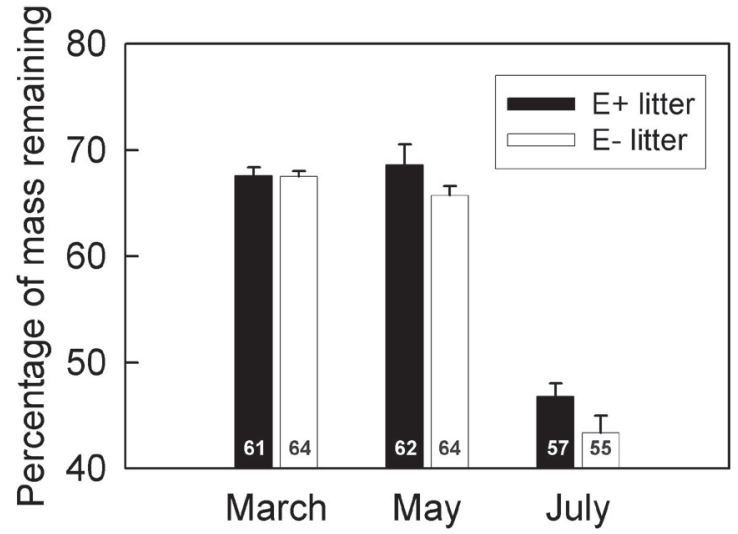

smaller for predators and parasitoids relative to invertebrate herbivores. In comparison, multitrophic level effects seem stronger in related grass-endophyte systems (e.g. perennial ryegrass-Argentine stem weevil-parasitoid, (Bultman et al. 1996, 1997), and Italian ryegrass-aphid-parasitoid interactions, (Omacini et al. 2001). However, surprisingly less attention has been given to multitrophic level interactions in the tall fescue system, given its ecological dominance, particularly in the USA.

The majority of studies testing for higher trophic level impacts of grass-endophyte interactions have examined parasitoids. Parasitoids typically have more specialised diets than predators of herbivores, and may be more sensitive to the presence of microbes in plants than other members of the third and fourth trophic levels. For example, Omacini et al. (2001) found that infected Lolium multiflorum (Italian ryegrass) reduced the rate of parasitism of aphids by several parasitoid species.

A broad range of possible effects on generalist predators could occur - from endophyte-mediated enhancement of predation to endophyte-mediated suppression. For example, entomopathogenic nematodes acted synergistically with the endophyte to reduce Japanese beetle (Popillia japonica) survival more than either factor alone (Grewal et al. 1995). In this case, fungal alkaloids appear responsible: reducing beetle consumption and mass and enhancing susceptibility to predation (Grewal et al. 1995). More recent work with Japanese beetles suggested a neutral effect of the endophyte on susceptibility to nematodes (Koppenhofer et al. 2003), and additional research is needed even

Figure 6 The change in endophyte frequency among treatments. The change in frequency was determined by subtracting the initial proportion of tillers infected in that plot from the proportion of tillers infected on each date. The change in proportion is bounded by 0.5 and $0.5(0 \%$ and $100 \%$ infected, respectively). Over time, infection increased in all plots (time, $\mathrm{F}_{8,47}=29.6, \mathrm{P}<0.0001$ ). Treatments diverged over time (fence $X$ insecticide $X$ time interaction, $\left.\mathrm{F}_{8,47}=2.8, \mathrm{P}<0.01\right)$. No main effects or two-way interactions were significant (fence, $F_{1,54}=3.1$, $\mathrm{P}<0.08$; fence $X$ time, $F_{8,47}=1.4, P<0.2$; insecticide, $F_{1,54}$ $=1.9, P<0.2$; insecticide $X$ time, $F_{8,47}=0.8, P<0.6$; fence $X$ insecticide, $\left.F_{1,54}=0.43, P<0.5\right)$. Symbols show means \pm SE and are slightly offset to show error bars clearly. $P$ values indicate a significant difference between the dual herbivore-exclusion treatment (fenced plus insecticide) and the control (unfenced plus water) for each date. Reprinted with permission from Clay et al. (2005).

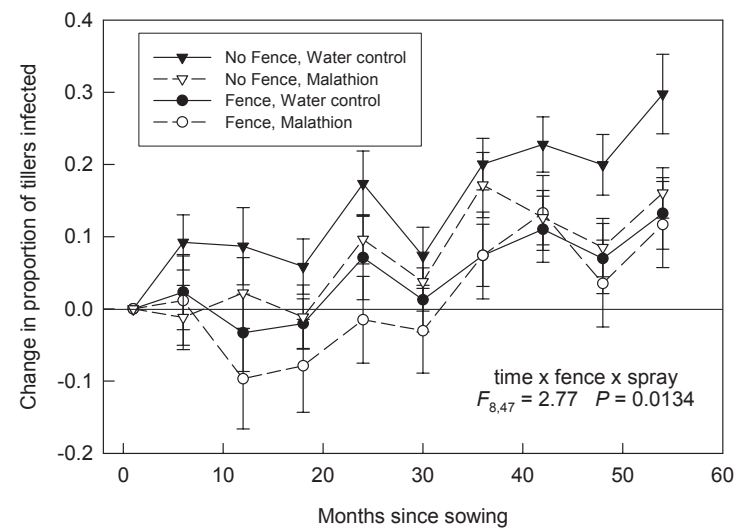


for this well-studied species. Surveys of generalist arthropod predator abundance in field plots suggest the ants, spiders (Aranae), and two beetle groups (Staphylinidae and Carabidae) may be insensitive to the presence of the endophyte (Bernard et al. 1997; Koppenhofer et al. 2003), at least when grouped at this broad taxonomic level. However, not all predator populations appear immune to, or benefit from, the endophyte. In fact, our work suggests that more attention to changes in composition within large taxonomic groups, such as order or family, is likely to reveal stronger endophyte effects. For example, while we found no effects of endophyte presence on the total abundance of spiders, there were significant reductions in the abundance of two important families: the crab spiders (Thomisidae) and sheet web-weaving spiders (Linyphiidae) due to the presence of the endophyte (Finkes et al. 2006, Fig. 7). At this stage, we can only speculate on mechanisms driving these effects, although prey capture rates were significantly lower for one common orbweaving spider (Araneidae) in $\mathrm{E}+$ versus E- tall fescue plots.

\section{Arthropod community structure}

Many studies have examined the effects of endophytes on individual herbivores, but few investigations have considered entire arthropod communities. In agronomic, as well as naturalised, tall fescue ecosystems, identification of these broader community level impacts are important to improving pest control and conserving biodiversity. We predict, based on studies with individual herbivores, that the endophyte in tall fescue will reduce the overall abundance and species richness of invertebrate herbivores. Reductions may occur directly through the deterrent action of fungal alkaloids and/or indirectly through reductions in plant diversity (bottom-up effect) or in the diversity of higher trophic levels (top-down effect). Most likely, for complex natural food webs, the endophyte will alter community structure through a multitude of direct and indirect pathways. To our knowledge, only three prior studies have experimentally tested for an effect of Neotyphodium coenophialum on the arthropod community as a whole; none surveyed comprehensively across taxa. Murphy et al (1993) found fewer total turfgrass pests in plots of $\mathrm{E}+$ tall fescue relative to E- plots. In a second study, endophyte symbiosis reduced two aphid species, two leafhoppers, a flea beetle, and staphylinid beetles, but had minimal effects on mites, predaceous arthropods, earthworms, Japanese beetles and three other aphid species (Davidson \& Potter 1995). Dissertation work by Willver (1996) (summarised in Bernard et al. 1997) found no effects of the endophyte on diplurans or carabid beetles, but declines in some groups of detritivores (Appendix 1). Unfortunately, most of these studies focused on the abundance responses of particular taxonomic groups and did not characterise other changes in community structure, such as species richness, taxonomic diversity, evenness, or composition. In one exception, (Muegge et al. 1991) found significant declines in the species richness of Cicadellidae and Cercopidae in field plots with the endophyte (Appendix 1).

Capturing these more detailed changes in community structure has been a goal of current research by our groups, because of our interest, more broadly, in understanding how mutualisms influence the dynamics of communities. In general, our results show that experimental elimination of the endophyte in tall fescue enhances the diversity of several guilds of arthropods, including herbivores, spiders and other predators, and increases the total abundance of insect herbivores (Rudgers \& Clay 2005 and unpublished data). These results indicate that finer-scale investigations of non-herbivore species are likely to reveal stronger effects of the endophyte than thus far reported.

\section{The role of endophyte genotype?}

Endophyte genotypes differ in compatibility with grass genotypes (Leuchtmann \& Clay 1989a; Christensen et al. 1997), production of alkaloids (Siegel et al. 1990; Hill et al. 1991; Wilkinson et al. 2000; Leuchtmann et al. 2000; Rasmussen et al. 2007), resistance to herbivores (Leuchtmann et al. 2000; Timper et al. 2001, 2005; Tintjer \& Rudgers 2006), production of stromata (Leuchtmann \& Clay 1989b), mycelial mass (Hiatt \& Hill 1997), and effects on the phenotypic plasticity of grasses (Cheplick 1998). Endophyte genotypes that differ in the types and amounts of alkaloids they produce can have dramatically different effects on plant enemies, particularly insect compared to mammalian herbivores. For example, endophyte genotypes have been introduced for forage grasses that lack the production of ergot alkaloids and consequently toxicity to livestock (Bouton et al. 2002). Similarly, the fungal alkaloid peramine affected one species of aphid, but combinations of both peramine and loline alkaloids were required for deterrence of other aphid species (Siegel et al. 1990; see also Hunt \& Newman 2005).

In ongoing work, we are exploring the relative importance of plant versus endophyte genotype in affecting the diversity

Figure 7 Effect of manipulation of the presence of Neotyphodium coenophialum in Lolium arundinaceum on the density of spiders in the families (a) Crab spiders (Thomisidae) and (b) Sheet web spiders (Linyphiidae) surveyed in $30 \mathrm{~m} \times 30 \mathrm{~m}$ field plots in Bloomington, Indiana. Data points represent the mean abundance of spiders, and the bars show \pm 1 SE. For the endophyte, treatments are represented as endophyte-infected $(\mathrm{E}+=$ solid circles) or endophyte-free ( $E-=$ open triangles), $n=8$ plots per treatment. Reprinted with permission from Finkes et al. (2005).

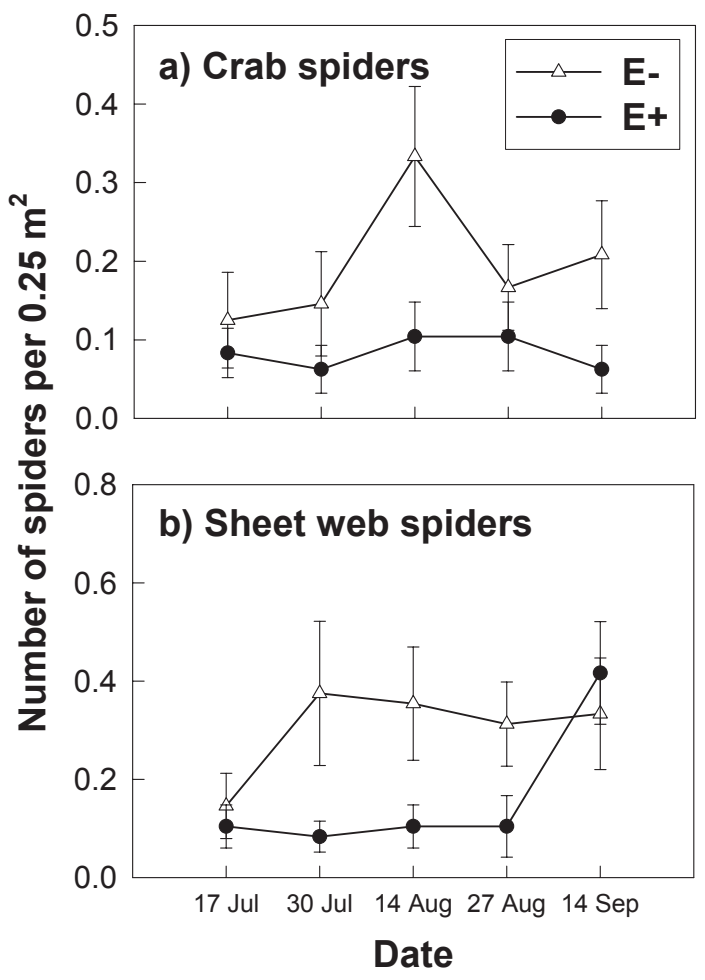


and abundance of other community members. Results thus far suggest that endophyte genotype does significantly alter plant and insect communities, but that these effects depend on the genetic background of tall fescue. Predicting how endophyte genotype alters community structure may ultimately depend on testing unique combinations of both host plant and microbe genotypes. Genetic modification of endophytes to eliminate the production of the mammalian toxin, ergovaline, has been accomplished (Panaccione et al. 2001), and directly incorporating genes from endophytic fungi into plant genomes has been proposed (Dahlman et al. 1991). To evaluate the environmental impacts of these advances, we will need to understand how variation in grass/ endophyte genotype combinations differentially affects ecological interactions within and between trophic levels in terrestrial communities. Because most infected tall fescue in the eastern USA is infected by a single endophyte genotype found in KY-31 and because it may be highly resistant to invasion by other species or genotypes, research on genetic variation in the endophyte may be of greater academic than practical significance except in highly managed agronomic and/or turf situations.

\section{Conclusions}

Our conclusions are based on experimental plots where fescue seed was sown on recently ploughed soil that was rapidly colonised by diverse plant and animal species. No treatments, if any, were applied following seeding so long-term community and ecosystem responses are integrating the cumulative effects of many varying biotic and abiotic factors. Results from multiple experiments are highly consistent and repeatable, suggesting that we are measuring general, rather than idiosyncratic, effects of endophyte infection on communities and ecosystems.

Several general conclusions arise from this work. One is that community-level effects are much stronger than one would predict from studies on individual species. Second, more generally, our results indicate an important role for mutualism in structuring communities and suggest that mutualisms may be critical for understanding the community and ecosystem-level consequences of non-native species such as tall fescue. Third, mechanisms of community change derive from a complex mixture of direct and indirect effects (e.g. through herbivores) of the endophyte. While we have identified vole herbivory as a key indirect mechanism, the relative importance of other factors (soil feedback, allelopathy, insect herbivory, direct competition, etc.) in mediating community-level responses is unclear and represents an important area for further study. Finally, it would be very useful to study community-level effects of endophyte symbiosis in other systems to improve generalisations and predictions, e.g. in tall fescue in different ecological settings (including where it is native), in L. perenne in Europe, USA and New Zealand, and in other dominant native and non-native grasses worldwide.

\section{ACKNOWLEDGEMENTS}

Most of this research was supported by NSF grant DBI-0200485 to Jennifer Rudgers and NSF grant DEB-9727116 to Keith Clay. Many thanks to the many post-docs, graduate students and undergraduate students who contributed to this research.

\section{REFERENCES}

Agee, C.S.; Hill, N.S. 1994. Ergovaline variability in Acremoniuminfected tall fescue due to environment and plant genotype. Crop Science 34: 221-226.

Bacon, C.W.; Porter, J.K.; Robbins, J.D. 1975. Toxicity and occurrence of Balansia on grasses from toxic fescue pastures. Applied Microbiology 29: 553-556.

Ball, D.M.; Pedersen, J.F.; Lacefield, G.D. 1993. The tall fescue endophyte. American Scientist 81: 370-379.

Bazely, D.R.; Vicari, M.; Emmerich, S.; Filip, L.; Lin, D.; Inman, A. 1997. Interactions between herbivores and endophyteinfected Festuca rubra from the Scottish islands of St. Kilda, Benbecula and Rum. Journal of Applied Ecology 34: 847-860.

Bernard, E.C.; Gwinn, K.D.; Pless, C.D.; Williver, C.L. 1997. Soil invertebrate species diversity and abundance in endophyteinfected tall fescue pastures. pp. 125-136. In: Neotyphodium/ Grass Interactions. Eds. Bacon, C.W.; Hill, N.S. Plenum Press, New York.

Bouton, J.H.; Latch, G.C. M.; Hill, N.S.; Hoveland, C.S.; McCann, M.A.; Watson, R.H.; Parish, J.A.; Hawkins, L.L.; Thompson, F.N. 2002. Reinfection of tall fescue cultivars with non-ergot alkaloid-producing endophytes. Agronomy Journal 94: 567-574.

Breen, J.P. 1994. Acremonium/endophyte interactions with enhanced plant resistance to insects. Annual Review of Entomology 39: 402-423.

Bultman, T.L.; Borowicz, K.L.; Coudron, T.A. 1996. Impact of a fungal endophyte on a tri-trophic level interaction. Bulletin of the Ecological Society of America 77: 60.

Bultman, T.L.; Borowicz, K.L.; Schneble, R.M.; Coudron, T.A.; Bush, L.P. 1997. Effect of a fungal endophyte on the growth and survival of two Euplectrus parasitoids. Oikos 78: 170-176.

Bush, L.P.; Wilkinson, H.H.; Schardl, C.L. 1997. Bioprotective alkaloids of grass-fungal endophyte symbioses. Plant Physiology 114: 1-7.

Cheplick, G.P. 1998. Genotypic variation in the regrowth of Lolium perenne following clipping: Effects of nutrients and endophytic fungi. Functional Ecology 12: 176-184.

Cheplick, G.P. 2004a. Recovery from drought stress in Lolium perenne (Poaceae): Are fungal endophytes detrimental. American Journal of Botany 91: 1960-1968.

Cheplick, G.P. 2004b. Symbiotic fungi and clonal plant physiology. New Phytologist 164: 413-415.

Cheplick, G.P.; Cho, R. 2003. Interactive effects of fungal endophyte infection and host genotype on growth and storage in Lolium perenne. New Phytologist 158: 183-191.

Cheplick, G.P.; Clay, K.; Marks, S. 1989. Interactions between infection by endophytic fungi and nutrient limitation in the grasses Lolium perenne and Festuca arundinacea. New Phytologist 111: 89-98.

Christensen, M.J.; Ball, O.J.P.; Bennett, R.J.; Schardl, C.L. 1997. Fungal and host genotype effects on compatibility and vascular colonization by Epichloe festucae. Mycological Research 101: 493-501.

Chu-chou, M.; Guo, G.; An, Z.Q.; Hendrix, J.W.; Ferris, R.S.; Siegel, M.R.; Dougherty, C.T.; Burrus, B.P. 1992. Suppression of mycorrhizal fungi in fescue by the Acremonium coenophialum endophyte. Soil Biology and Biochemistry 24: 633-637.

Clay, K. 1988. Fungal endophytes of grasses: a defensive mutualism between plants and fungi. Ecology 69: 10-16.

Clay, K. 1996. Interactions among fungal endophytes, grasses and herbivores. Researches on Population Ecology 38: 191-201.

Clay, K. 1997. Fungal endophytes, herbivores and the structure of grassland communities. pp. 151-169. In: Multitrophic Interactions in Terrestrial Systems. Eds. Gange, A.C.; Brown, V.K. Blackwell, Oxford.

Clay, K.; Cheplick, G.P. 1989. Effect of ergot alkaloids from fungal 
endophyte-infected grasses on fall armyworm (Spodoptera frugiperda). Journal of Chemical Ecology 15:169-182.

Clay, K.; Cheplick, G.P.; Marks, S. 1989. Impact of the fungus Balansia henningsiana on Panicum agrostoides: Frequency of infection, plant growth and reproduction, and resistance to pests. Oecologia 80: 374-380.

Clay, K.; Holah, J. 1999. Fungal endophyte symbiosis and plant diversity in successional fields. Science 285: 1742-1744.

Clay, K.; Holah, J.; Rudgers, J.A. 2005. Herbivores cause a rapid increase in hereditary symbiosis and alter plant community composition. Proceedings of the National Academy of Sciences U. S. A. 102: 12465-12470.

Clay, K.; Leuchtmann, A. 1989. Infection of woodland grasses by fungal endophytes. Mycologia 81:805-811.

Clay, K.; Marks, S.; Cheplick, G.P. 1993. Effects of insect herbivory and fungal endophyte infection on competitive interactions among grasses. Ecology 74:1767-1777.

Clay, K.; Schardl, C. 2002. Evolutionary origins and ecological consequences of endophyte symbiosis with grasses. American Naturalist 160:S99-S127.

Clement, S.L.; Kaiser, W.J.; Eichenseer, H. 1994. Acremonium endophytes in germplasms of major grasses and their utilization for insect resistance. pp. 185-199. In: Biotechnology of endophytic fungi of grasses. Eds. Bacon, C.W.; White, J.F.Jr. CRC Press, Boca Raton.

Craven, K.D.; Blankenship, J.D.; Leuchtmann, A.; Hignight, K.; Schardl, C.L. 2001a. Hybrid fungal endophytes symbiotic with the grass Lolium pratense. Sydowia 53: 44-73.

Craven, K.D.; Hsiau, P.T.W.; Leuchtmann, A.; Hollin, W.; Schardl, C.L. 2001b. Multigene phylogeny of Epichloe species, fungal symbionts of grasses. Annals of the Missouri Botanical Garden 88: 14-34.

Dahlman, D.L.; Eichenseer, H.; Siegel, M.R. 1991. Chemical perspectives on endophyte-grass interactions and their implications to insect herbivory. pp. 227-252. In: Microorganisms, plants and herbivores. Eds. Jones, C.; Krischik, V.; Barbosa. P. John Wiley and Sons, New York.

Davidson, A.W.; Potter, D.A. 1995. Response of plant-feeding, predatory, and soil-inhabiting invertebrates to Acremonium endophyte and nitrogen fertilization in tall fescue turf. Journal of Economic Entomology 88: 367-379.

De Battista, J.P.; Bouton, J.H.; Bacon, C.W.; Siegel, M.R. 1990. Rhizome and herbage production of endophyte-removed tall fescue clones and populations. Agronomy Journal 82: 651-654.

Elmi, A.A.; West, C.P.; Robbins, R.T.; Kirkpatrick, T.L. 2000. Endophyte effects on reproduction of a root-knot nematode (Meloidogyne marylandi) and osmotic adjustment in tall fescue. Grass and Forage Science 55: 166-172.

Faeth, S.H.; Gardner, D.R.; Hayes, C.J.; Jani, A.; Wittlinger, S.K.; Jones, T.A. 2006. Temporal and spatial variation in alkaloid levels in Achnatherum robustum, a native grass infected with the endophyte Neotyphodium. Journal of Chemical Ecology 32: 307-324.

Faeth, S.H.; Helander, M.L.; Saikkonen, K. 2004. Asexual Neotyphodium endophytes in a native grass reduce competitive abilities. Ecology Letters 7:304-313.

Faeth, S.H.; Sullivan, T.J. 2003. Mutualistic asexual endophytes in a native grass are usually parasitic. American Naturalist 161: 310-325.

Finkes, L.K.; Cady, A.B.; Mulroy, J.C.; Clay, K.; Rudgers, J.A. 2006. Plant-fungus mutualism affects spider composition in successional fields. Ecology Letters 9: 347-356.

Fortier, G.M.; Bard, N.; Jansen, M.; Clay, K. 2000. Effects of tall fescue endophyte infection and population density on growth and reproduction in prairie voles. Journal of Wildlife Management 64: 122-128.

Fortier, G.M.; Osmon, M.A.; Roach, M.; Clay, K. 2001. Are female voles food limited? Effects of endophyte-infected tall fescue on home range size in female prairie voles (Microtus ochrogaster). American Midland Naturalist 146: 63-71.

Fountain, M.T.; Hopkin, S.P. 2005. Folsomia candida (Collembola): A "standard" soil arthropod. Annual Review of Entomology 50: 201-222.

Francis, S.M.; Baird, D.B. 1989. Increase in the proportion of endophyte-infected perennial ryegrass plants in overdrilled pastures. New Zealand Journal of Agricultural Research 32: 437-440.

Franzluebbers, A. J. 2006. Short-term responses of soil C and $\mathrm{N}$ fractions to tall fescue endophyte infection. Plant and Soil 282: 153-164.

Franzluebbers, A.J.; Hill, N.S. 2005. Soil carbon, nitrogen, and ergot alkaloids with short- and long-term exposure to endophyte-infected and endophyte-free tall fescue. Soil Science Society of America Journal 69: 404-412.

Franzluebbers, A.J.; Nazih, N.; Stuedemann, J.A.; Fuhrmann, J.J.; Schomberg, H.H.; Hartel, P.G. 1999. Soil carbon and nitrogen pools under low- and high-endophyte-infected tall fescue. Soil Science Society of America Journal 63: 1687-1694.

Franzluebbers, A.J.; Stuedemann, J.A. 2005. Soil carbon and nitrogen pools in response to tall fescue endophyte infection, fertilization, and cultivar. Soil Science Society of America Journal 69: 396-403.

Grewal, S.K.; Grewal, P.S.; Gaugler, R. 1995. Endophytes of fescue grasses enhances susceptibility of Popillia japonica larvae to an entomopathogenic nematode. Entomologia Experimentalis et Applicata 74: 219-224.

Gwinn, K.D.; Collins-Shepard, M.H.; Reddick, B.B. 1991. Tissue print-immunoblot, an accurate method for the detection of Acremonium coenophialum in tall fescue. Phytopathology 81 : 747-748.

Hedges, L.V.; Gurevitch, J.; Curtis, P.S. 1999. The meta-analysis of response ratios in experimental ecology. Ecology 80: 11501156.

Hiatt, E.E.; Hill, N.S.; Bouton, J.H.; Stuedemann, J.A. 1999. Tall fescue endophyte detection: Commercial immunoblot test kit compared with microscopic analysis. Crop Science 39: 796-799.

Hiatt, E.E.; Hill, N.S.; Hiatt, E.N. 2001. Monoclonal antibodies incorporated into Neotyphodium coenophialum fungal cultures: Inhibition of fungal growth and stability of antibodies. Fungal Genetics and Biology 33: 107-114.

Hiatt, E.E.; Hill, N.S. 1997. Neotyphodium coenophialum mycelial protein and herbage mass effects on ergot alkaloid concentration in tall fescue. Journal of Chemical Ecology 23: 2721-2736.

Hill, N.S.; Hiatt, E.E.; De Battista, J.P.; Costa, M.C.; Griffiths, C.H.; Klap, J.; Thorogood, D.; Reeves, J.H. 2002. Seed testing for endophytes by microscopic and immunoblot procedures. Seed Science and Technology 30: 347-355.

Hill, N.S.; Parrott, W.A.; Pope, D.D. 1991. Ergopeptine alkaloid production by endophytes in a common tall fescue genotype. Crop Science 31: 1545-1547.

Hooper, D.U.; Vitousek. P.M. 1997. The effects of plant composition and diversity on ecosystem processes. Science 277: 1302-1305.

Humphries, S.S.; Gwinn, K.D.; Stewart, A.J. 2001. Effects of endophyte status of tall fescue tissues on the earthworm 
(Eisenia fetida). Environmental Toxicology and Chemistry 20: 1346-1350.

Hunt, M.G.; Newman, J.A. 2005. Reduced herbivore resistance from a novel grass-endophyte association. Journal of Applied Ecology 42: 762-769.

Kimmons, C.A.; Gwinn, K.D.; Bernard, E.C. 1990. Nematode reproduction on endophyte-infected and endophyte-free tall fescue. Plant Disease 74: 757-761.

Knoch, T.R.; Faeth, S.H.; Arnott, N.H. 1993. Endophytic fungi alter foraging and dispersal by desert seed-harvesting ants. Oecologia 95: 470-473.

Koppenhofer, A.M.; Cowles, R.S.; Fuzy, E.M. 2003. Effects of turfgrass endophytes (Clavicipitaceae : Ascomycetes) on white grub (Coleoptera : Scarabaeidae) larval development and field populations. Environmental Entomology 32: 895-906.

Koulman, A.; Lane, G.A.; Christensen, M.J.; Fraser, K.; Tapper, B.A. 2007. Peramine and other fungal alkaloids are exuded in the guttation fluid of endophyte-infected grasses. Phytochemistry 68: 355-360.

Kucht, S.; Grob, J.; Hussein, Y.; Grothe, T.; Keller, U.; Basar, S.; Konig, W.A.; Steiner, U.; Leister, E. 2004. Elimination of ergoline alkaloids following treatment of Ipomoea asarifolia (Convolvulaceae) with fungicides. Planta 219: 619-625.

Latch, G.C.M. 1993. Physiological interactions of endophytic fungi and their hosts: Biotic stress tolerance imparted to grasses by endophytes. Agriculture, Ecosystems and Environment 44:143-156.

Latch, G.C.M.; Potter, L.R.; Tyler, B.F. 1987. Incidence of endophytes in seeds from collections of Lolium and Festuca species. Annals of Applied Biology 111: 59-64.

Lemons, A.; Clay, K.; Rudgers, J.A. 2005. Connecting plantmicrobial interactions above and belowground: a fungal endophyte affects decomposition. Oecologia 145:595-604.

Leuchtmann, A. 1992. Systematics, distribution, and host specificity of grass endophytes. Natural Toxins 1:150-162.

Leuchtmann, A.; Clay, K. 1989a. Experimental evidence for genetic variation in compatibility between the fungus Atkinsonella hypoxylon and its three host grasses. Evolution 43: 825-834.

Leuchtmann, A.; Clay, K. 1989b. Morphological, cultural and mating studies on Atkinsonella, including Atkinsonella texensis new status. Mycologia 81: 692-701.

Leuchtmann, A.; Clay, K. 1990. Isozyme variation in the Acremonium/Epichloe fungal endophyte complex. Phytopathology 80: 1133-1139.

Leuchtmann, A.; Clay, K. 1996. Isozyme evidence for host races of the fungus Atkinsonella hypoxylon (Clavicipitaceae) infecting the Danthonia (Poaceae) complex in the southern Appalachians. American Journal of Botany 83: 1144-1152.

Leuchtmann, A.; Schmidt, D.; Bush, L.P. 2000. Different levels of protective alkaloids in grasses with stroma-forming and seedtransmitted Epichloe/Neotyphodium endophytes. Journal of Chemical Ecology 26: 1025-1036.

Lipsitch, M.; Nowak, M.A.; Ebert, D.; May, R.M. 1995. The population dynamics of vertically and horizontally transmitted parasites. Proceedings of the Royal Society of London Series B-Biological Sciences 260: 321-327.

Lipsitch, M.; Siller, S.; Nowak, M.A. 1996. The evolution of virulence in pathogens with vertical and horizontal transmission. Evolution 50: 1729-1741.

Madej, C.W.; Clay, K. 1991. Avian seed preference and weight loss. experiments: the effect of fungal endophyte-infected tall fescue. seeds. Oecologia 88: 296-303.
Malinowski, D.P.; Alloush, G.A.; Belesky, D.P. 1998. Evidence for chemical changes on the root surface of tall fescue in response to infection with the fungal endophyte Neotyphodium coenophialum. Plant and Soil 205: 1-12.

Malinowski, D.P.; Belesky, D.P. 2000. Adaptations of endophyteinfected cool-season grasses to environmental stresses: Mechanisms of drought and mineral stress tolerance. Crop Science 40: 923-940.

Matthews, J.W.; Clay, K. 2001. Influence of fungal endophyte infection on plant-soil feedback and community interactions. Ecology 82: 500-509.

Miles, C.O.; Di Menna, M.E.; Jacobs, S.W.L.; Garthwaite, I.; Lane, G.A.; Prestidge, R.A.; Marshall, S.L.; Wilkinson, H.H.; Schardl, C.L.; Ball, O.J.P.; Latch, G.C.M. 1998. Endophytic fungi in indigenous Australasian grasses associated with toxicity to livestock. Applied and Environmental Microbiology 64: 601-606.

Moon, C.D.; Craven, K.D.; Leuchtmann, A.; Clement, S.L.; Schardl. C.L. 2004. Prevalence of interspecific hybrids amongst asexual fungal endophytes of grasses. Molecular Ecology 13: 1455-1467.

Moon, C.D.; Miles, C.O.; Jarlfors, U.; Schardl, C.L. 2002. The evolutionary origins of three new Neotyphodium endophyte species from grasses indigenous to the Southern Hemisphere. Mycologia 94: 694-711.

Muegge, M.A.; Quisenberry, S.S.; Bates, G.E.; Joost. R.E. 1991. Influence of Acremonium infection and pesticide use on seasonal abundance of leafhoppers and froghoppers (Homoptera, Cicadellidae, Cercopidae) in tall fescue. Environmental Entomology 20: 1531-1536.

Murphy, J.A.; Sun, S.; Betts, L.L. 1993. Endophyte-enhanced resistance to billbug (Coleoptera: Curculionidae), sod webworm (Lepidoptera; Pyralidae), and white grub (Coleoptera; Scarabaeidae) in tall fescue. Environmental Entomology 22: 699-703.

Newman, J.A.; Abner, M.L.; Dado, R.J.; Gibson, D.J.; Brookings, A.; Parsons, A.J. 2003. Effects of elevated CO2, nitrogen and fungal endophyte-infection on tall fescue: growth, photosynthesis, chemical composition and digestibility. Global Change Biology 9: 425-437.

Oliver, J.B.; Pless, C.D.; Gwinn, K.D. 1990. Effect of endophyte, Acremonium coenophialum, in "Kentucky 31" tall fescue, Festuca arundinacea, on survival of Popillia japonica. pp. 173-175. In: Proceedings of the international symposium on Acremonium/Grass Interactions. Eds. Quisenberry, S.S.; Joost, R.E. Louisiana Agricultural Experimental Station, Baton Rouge, LA.

Omacini, M.; Chaneton, E.J.; Ghersa, C.M.; Muller, C.B. 2001. Symbiotic fungal endophytes control insect host-parasite interaction webs. Nature 409: 78-81.

Omacini, M.; Chaneton, E.J.; Ghersa, C.M.; Otero, P. 2004. Do foliar endophytes affect grass litter decomposition? A microcosm approach using Lolium multiflorum. Oikos 104: 581-590.

Omacini, M.; Eggers, T.; Bonkowski, M.; Gange, A.C.; Jones, T.H. 2006. Leaf endophytes affect mycorrhizal status and growth of co-infected and neighbouring plants. Functional Ecology 20: 226-232.

Orr, S.P.; Rudgers, J.A.; Clay, K. 2005. Invasive plants can inhibit native tree seedlings: testing potential allelopathic mechanisms. Plant Ecology 181: 153-165.

Pan, J.J.; Clay, K. 2002. Infection by the systemic fungus Epichloe glyceriae and clonal growth of its host grass Glyceria striata. 
Oikos 98: 37-46.

Pan, J.J.; Clay, K. 2003. Infection by the systemic fungus Epichloe glyceriae alters clonal growth of its grass host, Glyceria striata. Proceedings of the Royal Society of London Series B-Biological Sciences 270: 1585-1591.

Panaccione, D.G.; Johnson, R.D.; Wang, J.; Young, C.A.; Damrongkool, P.; Scott, B.; Schardl, C.L. 2001. Elimination of ergovaline from a grass-Neotyphodium endophyte symbiosis by genetic modification of the endophyte. Proceedings of the National Academy of Sciences of the United States of America 98: 12820-12825.

Pedersen, J.F.; Rodriguez-Kabana, R.; Shelby, R.A. 1988. Ryegrass cultivars and endophyte in tall fescue affect nematodes in grass and succeeding soybean. Agronomy Journal 80: 811-814.

Popay, A.J.; Bonos, S.A. 2005. Biotic responses in endophytic grasses. pp. 163-186. In: Neotyphodium in Cool-Season Grasses: Current Research and Applications. Eds. Roberts, C.; West, C.P.; Spiers, D.A. Blackwell, Ames, IA.

Rasmussen, S., Parsons, A.J.; Bassett, S.; Christensen, M.J.; Hume, D.E.; Johnson, L.J.; Johnson, R.D.; Simpson, W.R.; Stacke, C.; Voisey, C.R.; Xue, H.; Newman, J.A.. 2007. High nitrogen supply and carbohydrate content reduce fungal endophyte and alkaloid concentration in Lolium perenne. New Phytologist 173: 787-797.

Rice, J.S.; Pinkerton, B.W.; Stringer, W.C.; Undersander, D.J. 1990. Seed production in tall fescue as affected by fungal endophyte. Crop Science 30: 1303-1305.

Rudgers, J. A., and K. Clay. 2005. Fungal endophytes in terrestrial communities and ecosystems. pp 423-442. In: The Fungal Community. Eds. Dighton, E.J.; Oudemans, P.; White, J.F. Jr. M. Dekker, New York.

Rudgers, J.A.; Holah, J.; Orr, S.P.; Clay, K. 2007. Forest succession suppressed by an introduced plant-fungal symbiosis. Ecology: in press.

Rudgers, J.A.; Koslow, J.M.; Clay, K. 2004. Endophytic fungi alter relationships between diversity and ecosystem properties. Ecology Letters 7: 42-51.

Rudgers, J.A.; Mattingly, W.B.; Koslow, J.M. 2005. Mutualistic fungus promotes plant invasion into diverse communities. Oecologia 144: 463-471.

Rykard, D.M.; Bacon, C.W.; Luttrell, E.S. 1985. Host relations of Myriogenospora atramentosa and Balansia epichloe (Clavicipitaceae). Phytopathology 75: 950-956.

Saikkonen, K.; Ahlholm, J.; Helander, M.; Lehtimaki, S.; Niemelainen, O. 2000. Endophytic fungi in wild and cultivated grasses in Finland. Ecography 23: 360-366.

Shelby, R.A.; Dalrymple, L.W. 1987. Incidence and distribution of the tall fescue endophyte in the USA. Plant Disease 71: 783-786.

Shelby, R.A.; Dalrymple, L.W. 1993. Long-term changes of endophyte infection in tall fescue stands. Grass and Forage Science 48: 356-361.

Siegel, M.R.; Latch, G.C.M.; Bush, L.P.; Fannin, F.F.; Rowan, D.D.; Tapper, B.A.; Bacon, C.W.; Johnson, M.C. 1990. Fungal endophyte-infected grasses: alkaloid accumulation and aphid response. Journal of Chemical Ecology 16: 3301-3316.

Spyreas, G.; Gibson, D.J.; Basinger, M. 2001. Endophyte infection levels of native and naturalized fescues in Illinois and England. Journal of the Torrey Botanical Society 128: 25-34.

Stovall, M.E.; Clay, K. 1988. The effect of the fungus, Balansia cyperi Edg., on growth and reproduction of purple nutsedge, Cyperus rotundus L. New Phytologist 109: 351-360.
Thompson, R.W.; Fribourg, H.A.; Reddick, B.B. 1989. Sample intensity and timing for detecting Acremonium coenophialum incidence in tall fescue pastures. Agronomy Journal 81: 966-971.

Tilman, D. 1999. The ecological consequences of changes in biodiversity: a search for general principles. Ecology 80: 1455-1474.

Tilman, D., J. Hill, and C. Lehman. 2006. Carbon-negative biofuels from low-input high-diversity grassland biomass. Science 314: 1598-1600.

Timper, P.; Gates, R.N.; Bouton, J.H. 2001. Nematode reproduction in tall fescue infected with different endophyte strains. Phytopathology 91: S144.

Timper, P.; Gates, R.N.; Bouton, J.H. 2005. Response of Pratylenchus spp. in tall fescue infected with different strains of the fungal endophyte Neotyphodium coenophialum. Nematology 7: 105-110.

Tintjer, T.; Rudgers, J.A. 2006. Grass-herbivore interactions altered by strains of a native endophyte. New Phytologist 170: 513-521.

Tsai, H.F.; Liu, J.S.; Staben, C.; Christensen, M.J.; Latch, G.C.M.; Siegel, M.R.; Schardl, C.L. 1994. Evolutionary diversification of fungal endophytes of tall fescue grass by hybridization with Epichloe species. Proceedings of the National Academy of Sciences of the United States of America 91: 2542-2546.

Wei, Y.K.; Gao, Y.B.; Xu, H.; Su, D.; Zhang, X.; Wang, Y.H.; Lin, F.; Chen, L.; Nie, L.Y.; Ren, A. Z. 2006. Neotyphodium in native grasses in China and observations on endophyte/host interactions. Grass and Forage Science 61: 422-429.

West, C. P. 1994. Physiology and drought tolerance of endophyteinfected grasses. pp. 87-101. In: Biotechnology of endophytic fungi of grasses. Eds. Bacon, C.W.; White, J.F.Jr. CRC Press, Boca Raton.

West, C.P.; Izekor, E.; Oosterhuis, D.M.; Robbins, R.T. 1988. The effect of Acremonium coenophialum on the growth and nematode infestation of tall fescue. Plant and Soil 112:3-6.

White, J.F., Jr. 1987. Widespread distribution of endophytes in the Poaceae. Plant Disease 71: 340-342.

White, J.F.; Cole, G.T. 1985. Endophyte-host associations in forage grasses. I. Distribution of fungal endophytes in some species of Lolium and Festuca. Mycologia 77: 323-327.

White, J.F.; Cole, G.T. 1986. Endophyte-host associations in forage grasses. V. Occurrence of fungal endophytes in certain species of Bromus and Poa. Mycologia 78: 846-850.

White, J.F.; Halisky, P.M.; Sun, S.C.; Morgan-Jones, G.; Funk, C.R. 1992. Endophyte-host associations in grasses. XVI. Patterns of endophyte distribution in species of the tribe Agrostideae. American Journal of Botany 79: 472-477.

Wilkinson, H.H.; Siegel, M.R.; Blankenship, J.D.; Mallory,A.C.; Bush, L.P.; Schardl, C.L. 2000. Contribution of fungal loline alkaloids to protection from aphids in a grass-endophyte mutualism. Molecular Plant-Microbe Interactions 13: 1027-1033.

Wilson, A.D.; Clement, S.L.; Kaiser, W.J.; Lester, D.G. 1991. First report of clavicipitaceous anamorphic endophytes in Hordeum species. Plant Disease 75:215.

Young, C.A.; Bryant, M.K.; Christensen, M.J.; Tapper, B.A.; Bryan, G.T.; Scott, B. 2005. Molecular cloning and genetic analysis of a symbiosis-expressed gene cluster for lolitrem biosynthesis from a mutualistic endophyte of perennial ryegrass. Molecular Genetics and Genomics 274: 13-29.

Zabalgogeazcoa, I.; de Aldana, B.R.V.; Ciudad, A.G.; Criado, B.G. 2003. Fungal endophytes in grasses from semi-arid permanent grasslands of western Spain. Grass and Forage Science 58: 94-97. 


\section{Appendix 1}

Summary of recent studies on the effects of the tall fescue endophyte on wild animals. We included all studies published since 1996 identified by the search terms "tall fescue" and "endophyt*" and "herbivor*" (and replacing both tall fescue and endophyt* with species names) on Web of Science (with one notable exception (Muegge et al. 1991) because it examined a species richness response). We also included relevant data available in recent book chapters. We only included studies that experimentally manipulated endophyte presence in tall fescue and that recorded at least one fitness-related response variable to estimate animal performance. Where multiple variables were measured, an effect size was determined for each. Effect size is the log response ratio $=\ln \left(\mathrm{mean}_{\mathrm{E}-} / \mathrm{mean}_{\mathrm{E}+}\right)$. Direction of the effect is for E+ relative to E- (i.e., lower means the response variable was lower in E+ relative to E-). Neutral effects (assigned an effect size of zero) were those reported as non-significant following statistical analysis. Some treatment means had to be estimated from data presented in figures, and those are indicated in the table.

\begin{tabular}{|c|c|c|c|c|c|c|c|c|}
\hline Ref & Arthropod & Guild & Specialization & Direction & $\begin{array}{l}\text { Effect } \\
\text { size } \\
(\mathrm{L})\end{array}$ & Response variable & $\begin{array}{c}\text { Field } \\
\text { or Lab/ } \\
\text { Greenhouse }\end{array}$ & $\begin{array}{c}\text { Means } \\
\text { estimated } \\
\text { from } \\
\text { figures }\end{array}$ \\
\hline (1) & $\begin{array}{l}\text { Chaetocnema pulicaria } \\
\text { (beetle) }\end{array}$ & leaf chewer & $\begin{array}{l}\text { grass } \\
\text { specialist }\end{array}$ & lower & 0.88 & $\begin{array}{l}\text { percentage } \\
\text { survival of adults } \\
\text { after } 4 \mathrm{~d}\end{array}$ & field & \\
\hline (2) & $\begin{array}{l}\text { Peromyscus leucopus } \\
\text { (mouse) }\end{array}$ & seed predator & generalist & neutral & 0.00 & daily food intake & lab & \\
\hline (2) & $\begin{array}{l}\text { Peromyscus leucopus } \\
\text { (mouse) }\end{array}$ & seed predator & generalist & higher & -0.23 & urine volume & $\mathrm{lab}$ & \\
\hline (3) & Sminthuridae (Collembola) & detritivore & generalist & higher & $\mathrm{n} / \mathrm{a}$ & number per plot & field & \\
\hline (3) & $\begin{array}{l}\text { Lepidocyrtus cinereus } \\
\text { (Collembola) }\end{array}$ & detritivore & generalist? & lower & 0.75 & number per plot & field & $x$ \\
\hline (3) & Homidia socia (Collembola) & detritivore & generalist? & neutral & 0.00 & number per plot & field & \\
\hline (3) & Galumna sp. & detritivore & generalist & lower & 1.21 & number per plot & field & $x$ \\
\hline (3) & $\begin{array}{l}\text { Epilohmannia sp. } \\
\text { (oribatid mite) }\end{array}$ & detritivore & generalist & neutral & 0.00 & number per plot & field & \\
\hline (3) & Chloropidae (flies) & detritivore & generalist & lower & 0.92 & number per plot & field & $\mathrm{X}$ \\
\hline (3)) & Parajapyx isabellae (dipluran) & predator & generalist & neutral & 0.00 & number per plot & field & \\
\hline (3) & Carabidae (ground beetles) & predator & generalist & neutral & 0.00 & number per plot & field & \\
\hline (4) & $\begin{array}{l}\text { Spodoptera frugiperda } \\
\text { (caterpillar) }\end{array}$ & leaf chewer & generalist & lower & 0.34 & larval mass & greenhouse & $x$ \\
\hline (4) & $\begin{array}{l}\text { Spodoptera frugiperda } \\
\text { (caterpillar) }\end{array}$ & leaf chewer & generalist & slower & -0.04 & development time & greenhouse & $x$ \\
\hline (4) & $\begin{array}{l}\text { Spodoptera frugiperda } \\
\text { (caterpillar) }\end{array}$ & leaf chewer & generalist & higher & -0.16 & pupal mass & greenhouse & $x$ \\
\hline (4) & $\begin{array}{l}\text { Spodoptera frugiperda } \\
\text { (caterpillar) }\end{array}$ & leaf chewer & generalist & higher & -0.06 & $\begin{array}{l}\text { pupal mass in } \\
\text { induced plants } \\
\text { (pre-damaged) }\end{array}$ & greenhouse & $x$ \\
\hline (5) & $\begin{array}{l}\text { Spodoptera frugiperda } \\
\text { (caterpillar) }\end{array}$ & leaf chewer & generalist & higher & -0.22 & larval growth & greenhouse & \\
\hline (5) & $\begin{array}{l}\text { Spodoptera frugiperda } \\
\text { (caterpillar) }\end{array}$ & leaf chewer & generalist & faster & 0.05 & development time & greenhouse & \\
\hline (5) & Rhopalosiphum padi (aphid) & sap feeder & $\begin{array}{l}\text { grass } \\
\text { specialist }\end{array}$ & lower & 0.33 & apterae density & greenhouse & \\
\hline (6) & $\begin{array}{l}\text { Spodoptera frugiperda } \\
\text { (caterpillar) }\end{array}$ & leaf chewer & generalist & higher & -0.18 & larval mass & greenhouse & \\
\hline (6) & $\begin{array}{l}\text { Spodoptera frugiperda } \\
\text { (caterpillar) }\end{array}$ & leaf chewer & generalist & faster & 0.04 & development time & greenhouse & \\
\hline (6) & $\begin{array}{l}\text { Spodoptera frugiperda } \\
\text { (caterpillar) }\end{array}$ & leaf chewer & generalist & lower & 0.11 & pupal mass & greenhouse & \\
\hline (6) & $\begin{array}{l}\text { Spodoptera frugiperda } \\
\text { (caterpillar) }\end{array}$ & leaf chewer & generalist & neutral & 0.00 & survival & greenhouse & \\
\hline (6) & $\begin{array}{l}\text { Spodoptera frugiperda } \\
\text { (caterpillar) }\end{array}$ & leaf chewer & generalist & neutral & 0.00 & assimilation & greenhouse & \\
\hline (7) & $\begin{array}{l}\text { Euplectrus comstockii } \\
\text { (parasitoid wasp) }\end{array}$ & parasitoid & moderate & faster & 0.10 & $\begin{array}{l}\text { female } \\
\text { development time }\end{array}$ & lab & $x$ \\
\hline (7) & $\begin{array}{l}\text { Euplectrus comstockii } \\
\text { (parasitoid wasp) }\end{array}$ & parasitoid & moderate & lower & 0.41 & pupal mass & lab & $x$ \\
\hline (7) & $\begin{array}{l}\text { Euplectrus comstockii } \\
\text { (parasitoid wasp) }\end{array}$ & parasitoid & moderate & neutral & 0.00 & survival & lab & \\
\hline
\end{tabular}




\begin{tabular}{|c|c|c|c|c|c|c|c|c|}
\hline Ref & Arthropod & Guild & Specialization & Direction & $\begin{array}{l}\text { Effect } \\
\text { size } \\
(L)\end{array}$ & Response variable & $\begin{array}{c}\text { Field } \\
\text { or Lab/ } \\
\text { Greenhouse }\end{array}$ & $\begin{array}{l}\text { Means } \\
\text { estimated } \\
\text { from } \\
\text { figures }\end{array}$ \\
\hline (7) & $\begin{array}{l}\text { Euplectrus comstockii } \\
\text { (parasitoid wasp) }\end{array}$ & parasitoid & moderate & neutral & 0.00 & sex ratio & lab & \\
\hline (7) & $\begin{array}{l}\text { Euplectrus plathypenae } \\
\text { (parasitoid wasp) }\end{array}$ & parasitoid & moderate & neutral & 0.00 & development time & lab & \\
\hline (7) & $\begin{array}{l}\text { Euplectrus plathypenae } \\
\text { (parasitoid wasp) }\end{array}$ & parasitoid & moderate & lower & 0.37 & $\begin{array}{l}\text { female pupal } \\
\text { mass }\end{array}$ & lab & $x$ \\
\hline (7) & $\begin{array}{l}\text { Euplectrus plathypenae } \\
\text { (parasitoid wasp) }\end{array}$ & parasitoid & moderate & neutral & 0.00 & survival & lab & \\
\hline (7) & $\begin{array}{l}\text { Euplectrus plathypenae } \\
\text { (parasitoid wasp) }\end{array}$ & parasitoid & moderate & neutral & 0.00 & sex ratio & lab & \\
\hline (8) & Rhopalosiphum padi (aphid) & sap feeder & $\begin{array}{l}\text { grass } \\
\text { specialist }\end{array}$ & lower & 0.80 & $\begin{array}{l}\text { intrinsic rate of } \\
\text { increase }\end{array}$ & greenhouse & $x$ \\
\hline (8) & Rhopalosiphum padi (aphid) & sap feeder & $\begin{array}{l}\text { grass } \\
\text { specialist }\end{array}$ & lower & 1.56 & $\begin{array}{l}\text { intrinsic rate of } \\
\text { increase following } \\
\text { artificial clipping }\end{array}$ & greenhouse & $x$ \\
\hline (8) & Rhopalosiphum padi (aphid) & sap feeder & $\begin{array}{l}\text { grass } \\
\text { specialist }\end{array}$ & lower & 1.10 & $\begin{array}{l}\text { intrinsic rate of } \\
\text { increase (replicate } \\
\text { experiment) }\end{array}$ & greenhouse & $x$ \\
\hline (8) & Rhopalosiphum padi (aphid) & sap feeder & $\begin{array}{l}\text { grass } \\
\text { specialist }\end{array}$ & lower & 1.12 & $\begin{array}{l}\text { intrinsic rate } \\
\text { of increase } \\
\text { following artificial } \\
\text { clipping (replicate } \\
\text { experiment) }\end{array}$ & greenhouse & $x$ \\
\hline (9) & Diuraphis noxia (aphid) & sap feeder & $\begin{array}{l}\text { grass } \\
\text { specialist }\end{array}$ & lower & 3.40 & number per plant & greenhouse & $x$ \\
\hline (9) & Diuraphis noxia (aphid) & sap feeder & $\begin{array}{l}\text { grass } \\
\text { specialist }\end{array}$ & lower & 2.52 & number per plant & field & \\
\hline (10) & $\begin{array}{l}\text { Reithrodontomys humulis } \\
\text { (mouse) }\end{array}$ & $\begin{array}{l}\text { omnivore esp. } \\
\text { seeds }\end{array}$ & generalist & lower & 1.04 & $\begin{array}{l}\text { number caught } \\
\text { per plot }\end{array}$ & field & \\
\hline (10) & Blarina brevicauda (shrew) & omnivore & generalist & lower & 0.66 & $\begin{array}{l}\text { number caught } \\
\text { per plot }\end{array}$ & field & \\
\hline (10) & Microtus pinetorum (vole) & root feeder & generalist & lower & 0.56 & $\begin{array}{l}\text { number caught } \\
\text { per plot }\end{array}$ & field & \\
\hline (10) & Sigmodon hispidus(rat) & leaf chewer & generalist & neutral & 0.00 & $\begin{array}{l}\text { number caught } \\
\text { per plot }\end{array}$ & field & \\
\hline (12) & $\begin{array}{l}\text { Microtus pennsylvanicus } \\
\text { (vole) }\end{array}$ & leaf chewer & generalist & neutral & 0.00 & offspring number & lab & \\
\hline (12) & $\begin{array}{l}\text { Microtus pennsylvanicus } \\
\text { (vole) }\end{array}$ & leaf chewer & generalist & neutral & 0.00 & body mass & lab & \\
\hline (12) & $\begin{array}{l}\text { Microtus pennsylvanicus } \\
\text { (vole) }\end{array}$ & leaf chewer & generalist & neutral & 0.00 & survival at $21 \mathrm{C}$ & lab & \\
\hline (12) & $\begin{array}{l}\text { Microtus pennsylvanicus } \\
\text { (vole) }\end{array}$ & leaf chewer & generalist & lower & 1.29 & survival at $31 \mathrm{C}$ & lab & \\
\hline (13) & $\begin{array}{l}\text { Branta canadensis (Canada } \\
\text { goose) }\end{array}$ & leaf chewer & generalist & lower & 0.12 & body mass & field & $x$ \\
\hline (14) & Hematobia irritans (fly larva) & coprophage & generalist & lower & 0.94 & $\begin{array}{l}\text { \% pupae from } \\
\text { larvae in dung with } \\
\mathrm{N} \text {-formyl loline }\end{array}$ & lab & \\
\hline (14) & Hematobia irritans (fly larva) & coprophage & generalist & lower & 1.37 & $\begin{array}{l}\text { \% pupae from } \\
\text { larvae in dung } \\
\text { with ergotamine } \\
\text { tartrate }\end{array}$ & lab & \\
\hline (14) & Hematobia irritans (fly larva) & coprophage & generalist & lower & 0.10 & $\begin{array}{l}\text { pupal mass in } \\
\text { dung with } \mathrm{N} \text { - } \\
\text { formyl loline }\end{array}$ & lab & \\
\hline (14) & Hematobia irritans (fly larva) & coprophage & generalist & lower & 0.59 & $\begin{array}{l}\text { pupal mass } \\
\text { in dung with } \\
\text { ergotamine } \\
\text { tartrate }\end{array}$ & lab & \\
\hline (14) & Hematobia irritans (fly larva) & coprophage & generalist & lower & 0.62 & $\begin{array}{l}\% \text { adults from } \\
\text { larvae in dung with } \\
\mathrm{N} \text {-formyl loline }\end{array}$ & lab & \\
\hline
\end{tabular}


Specialization Direction size Response variable

(L)

Means

or Lab/ estimated Greenhouse from figures

$\%$ adults from

larvae in dung

with ergotamine tartrate

\begin{tabular}{lllllll}
\hline (14) Hematobia irritans (fly larva) coprophage & generalist & neutral & 0.00 & adult mass & lab
\end{tabular}

(14) Hematobia irritans (fly larva) coprophage generalist $\quad$ neutral 0.00 adult mass lab

(15) Microtus ochrogaster (vole) leaf chewer generalist lower 1.44 adult male growth lab

(15) Microtus ochrogaster (vole) leaf chewer generalist lower 0.86 growth rate of litters

(15) Microtus ochrogaster (vole) leaf chewer generalist lower 1.61 number of litters lab

(15) Microtus ochrogaster (vole) leaf chewer generalist lower 1.63 percentage of

(15) Microtus ochrogaster (vole) leaf chewer generalist lower 1.63 offspring surviving lab

to $21 \mathrm{~d}$

number of $\begin{array}{llllll}\text { (16) } \begin{array}{l}\text { Meloidogyne marylandi (root } \\ \text { knot nematode) }\end{array} & \begin{array}{l}\text { root } \\ \text { endoparasite }\end{array} & \begin{array}{l}\text { grass } \\ \text { specialist? }\end{array} & \text { lower } 3.98 \begin{array}{l}\text { number of } \\ \text { nematodes per } \\ \text { pot }\end{array} & \text { greenhouse }\end{array}$

(17) rabbit (species name not leaf chewer generalist lower 0.73 male body mass lab

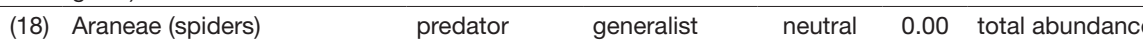

(18) Araneae (spiders) predator generalist lower 0.13 morphospecies

(18) Araneae (spiders) $\quad$ predator $\quad$ generalist $\quad$ lower 0.16 family richness

$\begin{array}{lllll}\text { (18) } \begin{array}{l}\text { Linyphidae (sheet web } \\ \text { spiders) }\end{array} & \text { predator generalist } & \text { lower } 0.63 & \begin{array}{l}\text { number per } \\ \text { subplot }\end{array}\end{array}$

(18) Thomisidae (crab spiders) predator generalist lower 0.85 number per

subplot

(18) Salticidae (jumping spiders) predator generalist higher -0.66 number per

(19) Microtus ochrogaster (vole) leaf chewer generalist $\quad$ neutral 0.00 number per plot field

(19) Microtus ochrogaster (vole) leaf chewer generalist higher -0.32 males (skewed field

$\begin{array}{llllll} & & \text { sex ratio) } & \\ \text { (19) Microtus ochrogaster (vole) leaf chewer generalist } \quad \text { neutral } & 0.00 & \begin{array}{l}\text { rate of sexual } \\ \text { maturity in males field }\end{array}\end{array}$

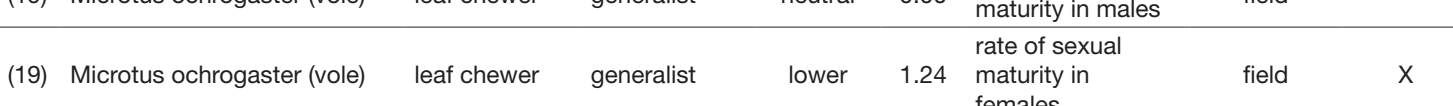

(19) Microtus ochrogaster (vole) leaf chewer generalist neutral $0.00 \begin{aligned} & \text { growth rate of } \\ & \text { individuals }\end{aligned} \quad$ field

(20) Microtus ochrogaster (vole) leaf chewer generalist $\quad$ neutral 0.00 home range size field

\begin{tabular}{lllllll}
\hline (21) Eisenia fetida (earthworm) & detritivore & generalist & neutral & 0.00 & survival & lab
\end{tabular}

(21) Eisenia fetida (earthworm) detritivore generalist greater -1.30 growth lab

\begin{tabular}{lllllll}
\hline (21) Eisenia fetida (earthworm) & detritivore & generalist & lower & 0.29 & reproduction & lab
\end{tabular}

grass intrinsic rate of

(22) Rhopalosiphum padi (aphid) sap feeder $\quad \begin{aligned} & \text { grass } \\ & \text { specialist }\end{aligned} \quad$ lower $1.28 \begin{aligned} & \text { increase (clip } \\ & \text { cage) }\end{aligned} \quad$ greenhouse $X$

(22) Rhopalosiphum padi (aphid) sap feeder $\quad \begin{aligned} & \text { grass } \\ & \text { specialist }\end{aligned} \quad$ lower $2.54 \begin{aligned} & \text { intrinsic rate } \\ & \text { of increase } \\ & \text { (enclosure) }\end{aligned} \quad$ greenhouse $\quad X$

\begin{tabular}{|c|c|c|c|c|c|c|c|}
\hline (23) & $\begin{array}{l}\text { Parapediasia teterrella } \\
\text { (webworm) }\end{array}$ & leaf chewer & $\begin{array}{l}\text { grass } \\
\text { specialist }\end{array}$ & lower & 4.44 & survival & \\
\hline$(24)$ & Exomala orientalis (beetle) & root feeder & generalist & higher & 1.03 & $\begin{array}{l}\text { susceptibility to } \\
\text { nematode }\end{array}$ & greenhouse \\
\hline$(24)$ & $\begin{array}{l}\text { Popilla japonica (Japanese } \\
\text { beetle) }\end{array}$ & root feeder & generalist & neutral & 0.00 & $\begin{array}{l}\text { susceptibility to } \\
\text { nematode }\end{array}$ & greenhouse \\
\hline$(24)$ & Cyclocephala borealis (beetle) & root feeder & generalist & neutral & 0.00 & $\begin{array}{l}\text { susceptibility to } \\
\text { nematode }\end{array}$ & greenhouse \\
\hline
\end{tabular}




\begin{tabular}{|c|c|c|c|c|c|c|c|c|}
\hline Ref & Arthropod & Guild & Specialization & Direction & $\begin{array}{l}\text { Effect } \\
\text { size } \\
(L)\end{array}$ & Response variable & $\begin{array}{c}\text { Field } \\
\text { or Lab/ } \\
\text { Greenhouse }\end{array}$ & $\begin{array}{c}\text { Means } \\
\text { estimated } \\
\text { from } \\
\text { figures }\end{array}$ \\
\hline (24) & Exomala orientalis (beetle) & root feeder & generalist & neutral & 0.00 & $\begin{array}{l}\text { susceptibility to } \\
\text { nematode }\end{array}$ & field & \\
\hline (24) & $\begin{array}{l}\text { Popilla japonica (Japanese } \\
\text { beetle) }\end{array}$ & root feeder & generalist & neutral & 0.00 & $\begin{array}{l}\text { susceptibility to } \\
\text { nematode }\end{array}$ & field & \\
\hline (24) & Cyclocephala borealis (beetle) & root feeder & generalist & neutral & 0.00 & $\begin{array}{l}\text { susceptibility to } \\
\text { nematode }\end{array}$ & field & \\
\hline$(24)$ & Formicidae (ants) & predator & generalist & neutral & 0.00 & number per plot & field & \\
\hline$(24)$ & Araneae (spiders) & predator & generalist & neutral & 0.00 & number per plot & field & \\
\hline$(24)$ & Staphylinidae (beetles) & predator & generalist & neutral & 0.00 & number per plot & field & \\
\hline$(24)$ & Carabidae (ground beetles) & predator & generalist & neutral & 0.00 & number per plot & field & \\
\hline$(24)$ & Exomala orientalis (beetle) & root feeder & generalist & lower & 0.63 & survival & greenhouse & \\
\hline$(24)$ & Exomala orientalis (beetle) & root feeder & generalist & neutral & 0.00 & body mass & greenhouse & \\
\hline (24) & $\begin{array}{l}\text { Popilla japonica (Japanese } \\
\text { beetle) }\end{array}$ & root feeder & generalist & neutral & 0.00 & survival & greenhouse & \\
\hline (24) & $\begin{array}{l}\text { Popilla japonica (Japanese } \\
\text { beetle) }\end{array}$ & root feeder & generalist & neutral & 0.00 & body mass & greenhouse & \\
\hline$(24)$ & Exomala orientalis (beetle) & root feeder & generalist & lower & 0.76 & survival & field & \\
\hline$(24)$ & Exomala orientalis (beetle) & root feeder & generalist & neutral & 0.00 & body mass & field & \\
\hline (24) & $\begin{array}{l}\text { Popilla japonica (Japanese } \\
\text { beetle) }\end{array}$ & root feeder & generalist & neutral & 0.00 & survival & field & \\
\hline (24) & $\begin{array}{l}\text { Popilla japonica (Japanese } \\
\text { beetle) }\end{array}$ & root feeder & generalist & lower & 0.19 & body mass & field & \\
\hline (24) & $\begin{array}{l}\text { white grubs (all species, } \\
\text { Scarabidae) }\end{array}$ & root feeder & generalist & higher & -0.56 & $\begin{array}{l}\text { number per plot } \\
\text { (avg of several } \\
\text { censuses) }\end{array}$ & field & \\
\hline$(25)$ & Collembola & detritivore & generalist & neutral & 0.00 & number per plot & & \\
\hline$(25)$ & Hypogastruridae (collembola) & detritivore & generalist & higher & -0.52 & number per plot & & \\
\hline$(25)$ & Isotomidae (collembola) & detritivore & generalist & lower & 0.36 & number per plot & & \\
\hline (26) & $\begin{array}{l}\text { Spodoptera frugiperda } \\
\text { (caterpillar) }\end{array}$ & leaf chewer & generalist & lower & 0.36 & $\begin{array}{l}\text { relative growth } \\
\text { rate }\end{array}$ & greenhouse & \\
\hline$(27)$ & Schistocerca gregaria (locust) & leaf chewer & generalist & neutral & 0.00 & survival & field & \\
\hline (28) & Agallia constricta (leafhopper) & sap feeder & $\begin{array}{l}\text { grass } \\
\text { specialist }\end{array}$ & lower & 0.73 & number per plot & field & $x$ \\
\hline (28) & Agallia deleta (leafhopper) & sap feeder & $\begin{array}{l}\text { grass } \\
\text { specialist }\end{array}$ & neutral & 0.00 & number per plot & field & $x$ \\
\hline (28) & $\begin{array}{l}\text { Draeculacephala spp. } \\
\text { (leafhopper) }\end{array}$ & sap feeder & generalist & lower & 1.06 & number per plot & field & $x$ \\
\hline (28) & $\begin{array}{l}\text { Exitianus exitiosus } \\
\text { (leafhopper) }\end{array}$ & sap feeder & $\begin{array}{l}\text { grass } \\
\text { specialist }\end{array}$ & lower & 1.43 & number per plot & field & $x$ \\
\hline (28) & $\begin{array}{l}\text { Graminella nigrifrons } \\
\text { (leafhopper) }\end{array}$ & sap feeder & & lower & 1.67 & number per plot & field & $x$ \\
\hline$(28)$ & Unerus colonus (leafhopper) & sap feeder & & neutral & 0.00 & number per plot & field & $x$ \\
\hline (28) & $\begin{array}{l}\text { Prosapia bicincta } \\
\text { (froghopper) }\end{array}$ & sap feeder & $\begin{array}{l}\text { grass } \\
\text { specialist }\end{array}$ & lower & 1.59 & number per plot & field & $x$ \\
\hline (28) & $\begin{array}{l}\text { species diversity (cicadellidae } \\
\text { and cercopidae) }\end{array}$ & sap feeder & & lower & 0.26 & $\begin{array}{l}\text { species diversity } \\
\text { (index not given) }\end{array}$ & field & $x$ \\
\hline (29) & Rhopalosiphum padi (aphid) & sap feeder & $\begin{array}{l}\text { grass } \\
\text { specialist }\end{array}$ & neutral & 0.00 & $\begin{array}{l}\text { number of apterae } \\
\text { per plant }\end{array}$ & greenhouse & \\
\hline (30) & $\begin{array}{l}\text { Balannococcus poae } \\
\text { (mealybug) }\end{array}$ & sap feeder & $\begin{array}{l}\text { grass } \\
\text { specialist }\end{array}$ & lower & 2.41 & $\begin{array}{l}\text { percentage } \\
\text { infestation }\end{array}$ & & \\
\hline (31) & $\begin{array}{l}\text { Popilla japonica (Japanese } \\
\text { beetle) }\end{array}$ & root feeder & generalist & neutral & 0.00 & body mass & greenhouse & \\
\hline (31) & $\begin{array}{l}\text { Popilla japonica (Japanese } \\
\text { beetle) }\end{array}$ & root feeder & generalist & neutral & 0.00 & survival & greenhouse & \\
\hline (32) & $\begin{array}{l}\text { Phenococcus solani } \\
\text { (mealybug) }\end{array}$ & sap feeder & $\begin{array}{l}\text { grass } \\
\text { specialist }\end{array}$ & lower & 4.19 & number per plant & greenhouse & \\
\hline (32) & $\begin{array}{l}\text { Phenococcus solani } \\
\text { (mealybug) }\end{array}$ & sap feeder & $\begin{array}{l}\text { grass } \\
\text { specialist }\end{array}$ & lower & 3.43 & number per plant & greenhouse & \\
\hline
\end{tabular}




\begin{tabular}{|c|c|c|c|c|c|c|c|c|}
\hline Ref & Arthropod & Guild & Specialization & Direction & $\begin{array}{l}\text { Effect } \\
\text { size } \\
(L)\end{array}$ & Response variable & $\begin{array}{c}\text { Field } \\
\text { or Lab/ } \\
\text { Greenhouse }\end{array}$ & $\begin{array}{l}\text { Means } \\
\text { estimated } \\
\text { from } \\
\text { figures }\end{array}$ \\
\hline (32) & Sipha maydis (aphid) & sap feeder & $\begin{array}{l}\text { grass } \\
\text { specialist }\end{array}$ & lower & 0.84 & number per plant & greenhouse & \\
\hline (33) & $\begin{array}{l}\text { Peromyscus leucopus } \\
\text { (mouse) }\end{array}$ & seed predator & generalist & neutral & 0.00 & body mass - male & $l a b-62 d$ & \\
\hline (33) & $\begin{array}{l}\text { Peromyscus leucopus } \\
\text { (mouse) }\end{array}$ & seed predator & generalist & neutral & 0.00 & $\begin{array}{l}\text { body mass - } \\
\text { female }\end{array}$ & $l a b-62 d$ & \\
\hline (33) & $\begin{array}{l}\text { Peromyscus leucopus } \\
\text { (mouse) }\end{array}$ & seed predator & generalist & neutral & 0.00 & $\begin{array}{l}\text { reproductive organ } \\
\text { mass - male }\end{array}$ & $l a b-62 d$ & \\
\hline (33) & $\begin{array}{l}\text { Peromyscus leucopus } \\
\text { (mouse) }\end{array}$ & seed predator & generalist & neutral & 0.00 & $\begin{array}{l}\text { reproductive organ } \\
\text { mass - female }\end{array}$ & $l a b-62 d$ & \\
\hline (33) & $\begin{array}{l}\text { Peromyscus leucopus } \\
\text { (mouse) }\end{array}$ & seed predator & generalist & neutral & 0.00 & body mass - male & $l a b-113 d$ & \\
\hline (33) & $\begin{array}{l}\text { Peromyscus leucopus } \\
\text { (mouse) }\end{array}$ & seed predator & generalist & neutral & 0.00 & $\begin{array}{l}\text { body mass - } \\
\text { female }\end{array}$ & $l a b-113 d$ & \\
\hline (33) & $\begin{array}{l}\text { Peromyscus leucopus } \\
\text { (mouse) }\end{array}$ & seed predator & generalist & neutral & 0.00 & $\begin{array}{l}\text { reproductive organ } \\
\text { mass - male }\end{array}$ & $l a b-113 d$ & \\
\hline (33) & $\begin{array}{l}\text { Peromyscus leucopus } \\
\text { (mouse) }\end{array}$ & seed predator & generalist & neutral & 0.00 & $\begin{array}{l}\text { reproductive organ } \\
\text { mass - female }\end{array}$ & $l a b-113 d$ & \\
\hline (33) & $\begin{array}{l}\text { Peromyscus leucopus } \\
\text { (mouse) }\end{array}$ & seed predator & generalist & neutral & 0.00 & $\begin{array}{l}\text { mean number of } \\
\text { litters per female }\end{array}$ & $l a b-113 d$ & \\
\hline (33) & $\begin{array}{l}\text { Peromyscus leucopus } \\
\text { (mouse) }\end{array}$ & seed predator & generalist & neutral & 0.00 & $\begin{array}{l}\text { number of } \\
\text { offspring per litter }\end{array}$ & $l a b-113 d$ & \\
\hline (33) & $\begin{array}{l}\text { Peromyscus leucopus } \\
\text { (mouse) }\end{array}$ & seed predator & generalist & neutral & 0.00 & $\begin{array}{l}\text { body mass - } \\
\text { unpaired female }\end{array}$ & $l a b-113 d$ & \\
\hline (33) & $\begin{array}{l}\text { Peromyscus leucopus } \\
\text { (mouse) }\end{array}$ & seed predator & generalist & neutral & 0.00 & $\begin{array}{l}\text { reproductive organ } \\
\text { mass - unpaired } \\
\text { female }\end{array}$ & $l a b-113 d$ & \\
\hline (34) & Acromyrmex versicolor (ant) & leaf chewer & generalist & lower & 0.97 & $\begin{array}{l}\text { queen survival } \\
\text { time }\end{array}$ & lab & $\mathrm{X}$ \\
\hline (34) & Acromyrmex versicolor (ant) & leaf chewer & generalist & lower & 13.16 & $\begin{array}{l}\text { queen percentage } \\
\text { survival after } 11 \\
\text { wks }\end{array}$ & lab & \\
\hline (34) & Acromyrmex versicolor (ant) & leaf chewer & generalist & neutral & 0.00 & worker number & lab & \\
\hline (34) & Acromyrmex versicolor (ant) & leaf chewer & generalist & lower & 12.15 & fungal garden size & lab & \\
\hline (35) & $\begin{array}{l}\text { Agrotis ipsilon (black } \\
\text { cutworm) }\end{array}$ & leaf chewer & generalist & neutral & 0.00 & larval mass & greenhouse & \\
\hline (35) & $\begin{array}{l}\text { Agrotis ipsilon (black } \\
\text { cutworm) }\end{array}$ & leaf chewer & generalist & neutral & 0.00 & pupal mass & greenhouse & \\
\hline (35) & $\begin{array}{l}\text { Agrotis ipsilon (black } \\
\text { cutworm) }\end{array}$ & leaf chewer & generalist & neutral & 0.00 & $\begin{array}{l}\text { days to } \\
\text { emergence }\end{array}$ & greenhouse & \\
\hline (35) & $\begin{array}{l}\text { Agrotis ipsilon (black } \\
\text { cutworm) }\end{array}$ & leaf chewer & generalist & neutral & 0.00 & $\begin{array}{l}\text { percentage } \\
\text { survival }\end{array}$ & greenhouse & \\
\hline
\end{tabular}

\begin{tabular}{ll}
\hline average & 0.66 \\
\hline vertebrate herbivores & 0.31 \\
\hline leaf chewers & 0.54 \\
\hline seed predators & 0.05 \\
\hline invertebrate herbivores & 1.01 \\
\hline sap feeders & 1.47 \\
\hline leaf chewers & 1.59 \\
\hline root feeders & 0.33 \\
\hline generalist & 0.74 \\
\hline grass specialist & 1.84 \\
\hline non-herbivores & 0.24 \\
\hline detritivores & 0.15 \\
\hline predators/parasitoids & 0.10 \\
\hline
\end{tabular}


1. O. J. P. Ball, C. Pless, K. D. Gwinn, in Neotyphodium/Grass Interactions C. W. Bacon, N. S. Hill, Eds. (Plenum Press, New York, New York, 1997) pp. 243-246.

2. J. L. Barger, M. G. Tannenbaum, Journal of Mammalogy 79, 464 (1998).

3. E. C. Bernard, K. D. Gwinn, C. D. Pless, C. L. Williver, in Neotyphodium/Grass Interactions C. W. Bacon, N. S. Hill, Eds. (Plenum Press, New York, 1997) pp. 125-136.

4. R. A. Boning, T. L. Bultman, American Midland Naturalist 136, 328 (1996).

5. T. L. Bultman, G. D. Bell, Oikos 103, 182 (2003).

6. T. L. Bultman, N. J. Conard, Environmental Entomology 27, 631 (1998).

7. T. L. Bultman, K. L. Borowicz, R. M. Schneble, T. A. Coudron, L. P. Bush, Oikos 78, 170 (1997).

8. T. L. Bultman, G. Bell, W. D. Martin, Ecology 85, 679 (2004).

9. S. L. Clement, D. G. Lester, A. D. Wilsokn, R. C. Johnson, J. H. Bouton, Journal of Economic Entomology 89, 766 (1996).

10.A. B. Coley, H. A. Fribourg, M. R. Pelton, K. D. Gwinn, Journal of Environmental Quality 24, 472 (1995).

11.P. D. Coley, Climate Change 39, 455 (1998).

12. M. R. Conover, Journal of Mammalogy 79, 457 (1998).

13. M. R. Conover, T. A. Messmer, Auk 98, 859 (1996).

14. C. T. Dougherty, F. W. Knapp, L. P. Bush, Journal of Medical Entomology 36, 73 (1999).

15. W. F. Durham, M. G. Tannenbaum, Canadian Journal of Zoology 76, 960 (1998).

16. A. A. Elmi, C. P. West, R. T. Robbins, T. L. Kirkpatrick, Grass and Forage Science 55, 166 (2000).

17. N. M. Filipov et al., Journal of Animal Science 76, 2456 (1998).

18. L. K. Finkes, A. B. Cady, J. C. Mulroy, K. Clay, J. A. Rudgers, Ecology Letters 9, 347 (2006).

19. G. M. Fortier, N. Bard, M. Jansen, K. Clay, Journal of Wildlife
Management 64, 122 (2000).

20. G. M. Fortier, M. A. Osmon, M. Roach, K. Clay, American Midland Naturalist 146, 63 (2001).

21.S. S. Humphries, K. D. Gwinn, A. J. Stewart, Environmental Toxicology and Chemistry 20, 1346 (2001).

22. M. G. Hunt, J. A. Newman, Journal of Applied Ecology 42, 762 (Aug, 2005).

23. H. Koga, Y. Hirai, K. Kanda, T. Tsukiboshi, T. Uematsu, JarqJapan Agricultural Research Quarterly 31, 109 (1997).

24. A. M. Koppenhofer, R. S. Cowles, E. M. Fuzy, Environmental Entomology 32, 895 (2003).

25.A. Lemons, K. Clay, J. A. Rudgers, Oecologia 145, 595 (2005).

26. S. Marks, D. E. Lincoln, Environmental Entomology 25, 618 (1996).

27. A. R. McLeod, A. Rey, K. K. Newsham, G. C. Lewis, P. Wolferstan, Journal of Photochemistry and Photobiology B Biology 62, 97 (2001).

28. M. A. Muegge, S. S. Quisenberry, G. E. Bates, R. E. Joost, Environmental Entomology 20, 1531 (1991).

29. J. C. Murphy, T. L. Bultman, in Neotyphodium/Grass Interactions C. W. Bacon, N. S. Hill, Eds. (Plenum Press, New York, New York, 1997) pp. 187-190.

30. C. Pennell, O. J. P. Ball, Proceedings of the 52nd N. Z. Plant Protection Conference 1999, 259 (1999).

31.D. S. Richmond, P. S. Grewal, J. Cardina, Journal of Vegetation Science 14, 835 (2003).

32. M. R. Sabzalian, B. Hatami, A. Mirlohi, Entomologia Experimentalis et Applicata 113, 205 (2004).

33. M. G. Tannenbaum, S. L. Seematter, D. M. Zimmerman, American Midland Naturalist 139, 114 (1998).

34. T. M. Tibbets, S. H. Faeth, Oecologia 118, 297 (1999).

35. R. C. Williamson, D. A. Potter, Journal of Economic Entomology 90, 1290 (1997). 